\title{
REVIEW
}

\section{Bluetongue: Indian perspective}

\author{
K. RANJAN ${ }^{1,2}$, P. MINAKSHI ${ }^{2}$, G. PRASAD ${ }^{3}$
}

\begin{abstract}
${ }^{1}$ Department of Veterinary Physiology and Biochemistry, Sardar Vallabhbhai Patel University of Agriculture and Technology, Meerut, Uttar Pradesh, 250110, India; ${ }^{2}$ Department of Animal Biotechnology, Lala Lajpat Rai University of Veterinary and Animal Sciences, Hisar, Haryana, 125004, India; ${ }^{3}$ Indian Council of Agricultural Research, New Delhi, India
\end{abstract}

\begin{abstract}
Summary. - Bluetongue (BT) is an insect borne (Culicoides) viral disease of small ruminants in India. While seroprevalence for BT is observed mostly in domestic and wild ruminant animals, the clinical form of disease and severe mortality is observed in sheep. Since the first report of BT in 1960s the country became endemic for the disease and most of the BT virus (BTV) serotypes (22 out of 27 worldwide) have been reported. The genome sequence analyses of these viruses revealed that both the eastern and western topotypes as well as their reassortant strains are present in India. It further revealed that some of these viruses are very close to live vaccines used in other countries. The severe economic concern justifies the need to develop sensitive and reliable diagnostic tests for BT. The virus isolation followed by identification by electron microscopy is gold standard test, but it is time consuming and not easily available in all the laboratories. Therefore, nucleic acid-based rapid diagnostic tests such as PCR, real-time PCR etc. are used nowadays. The BT control program in India includes vector control as well as effective vaccination. The vector population is controlled by vector traps, synthetic pesticides and some of the herbal compounds. For effective vaccination, the serotypes prevalent in a particular geographical area must be known, which can be achieved by continuous monitoring and sero-surveillance of disease. The multivalent inactivated vaccines are more suitable for India in comparison to modified live vaccines as the latter may turn to virulent and may lead to severe outbreak of the disease.
\end{abstract}

Keywords: bluetongue virus; Culicoides; PCR; nucleic acid sequencing; India

\section{Contents:}

1. Introduction

2. Economic impact of BT in India

3. BTV genome arrangement

4. Susceptibility of Indian sheep breeds to BT

5. Culicoides vectors and BTV infection in India

6. Bluetongue epidemiology in India

6.1 First phase of BT

6.2 Endemic phase of BT

6.3 Recent BT outbreak in India

7. Phylogenetic analysis and sequence diversity of Indian BTV isolates

E-mail: drkoushleshranjan@gmail.com; phone: +91-8265965696. Abbreviations: AGID = Agar Gel Immunediffusion; BT = bluetongue, $\mathrm{BTV}=$ bluetongue virus, $\mathrm{MLV}=$ modified live virus
8. Differential diagnosis

9. Diagnosis

9.1 Virus isolation

9.2 Immunological detection of the virus

9.3 Nucleic-acid-based diagnosis

10. Prevention and control of BT

11. BT control strategy

11.1 Control strategies based on animal involvement

11.1.1 Vaccination of animals

11.1.2 Trade restrictions, culling and housing of animals

11.2 Control strategies based on vector involvement

11.2.1 Control of immature Culicoides (larvae)

11.2.2 Control of mature Culicoides

12. Lessons learnt from BT for India and other countries

13. BTV research and future perspective

14. Conclusion 


\section{Introduction}

Bluetongue (BT) is one of the important viral disease of domestic and wild ruminants in India. It is transmitted by the Culicoides (bitting midges) vector. The disease is caused by non-enveloped icosahedral bluetongue virus (BTV), which belongs to the genus Orbivirus and the family Reoviridae. It can infect all species of ruminants especially small ruminants such as sheep (Maclachlan and Guthrie, 2010). The clinical signs of BTV infection are more severe and confined to mostly white-tailed deer and sheep (Darpel et al., 2007). The cattle or buffalo are clinically not affected by BT. They act as reservoir for the disease (Luedke and Jones, 1984). Exceptionally, however, BTV8 was reported from clinically infected cattle (Elbers et al., 2008). BT is listed under the category of multiple species diseases by Office International des Epizooties (OIE, 2013). Globally, twenty seven distinct BTV serotypes have been reported so far. Any of these serotypes is thought to be capable of causing BT in animals. BTV serotypes 25, 26 and 27 have been recently isolated from Switzerland, Kuwait and France, respectively (Hofmann et al., 2008; Maan et al., 2011; Jenckel et al., 2015). The segmented nature of BTV genome allows the reassortment of genome segments, especially when mammalian host or Culicoides vector is simultaneously infected by two or more different BTV serotypes. This led to the evolution of new isolates and serotypes of BTV (Batten et al., 2008).

The Indian subcontinent lies between $8.4^{\circ} \mathrm{N}$ and $37.6^{\circ} \mathrm{N}$ and $68.7^{\circ} \mathrm{E}$ and $97.25^{\circ} \mathrm{E}$. The overall climate of India is hot and humid. The monsoon enters the India first in southern region during late May or early June and reaches to north later on. Thus, June to October is the months of rain-bearing monsoon. The monsoon season is favorable to various insect vectors (including Culicoides) and infectious diseases (like BT) transmitted by them. The several species of domestic and wild ruminants of India are known to be significantly susceptible to BTV infection. The large population of susceptible animals along with favorable climatic conditions made India endemic for BT.

\section{Economic impact of BT in India}

The BT disease has a potential to spread rapidly. Thus, it creates one of the major barriers in International Trade of animals and its products. It causes economic losses in terms of high morbidity, mortality, abortion, fetal death and deformities as well as milk, meat and fleece losses. On average $2 \%-30 \%$ of the animals infected by BT die. However, the number may reach up to $100 \%$ in highly susceptible sheep. BT caused death of 300,000 sheep and goats in Tamil Nadu during the monsoon season of 1997-1998 (Ilango, 2006). It is the major contributing factor for annual economic losses in Indian sheep industry. During 1991-2005, BT caused maximum economic losses (60.8\%) among all infectious diseases in sheep. Due to its possible socio-economic consequences, mandatory export restrictions and surveillance requirements are imposed on movement of live animals and its products, germplasm, embryo from BT-endemic to BTfree countries (Velthuis et al., 2009). BT affects particularly native sheep population and causes high mortality, overall loss of productivity, weight loss and wool break. Thus it causes significant economic losses to less-affluent farming community, because native sheep is mainly reared by these farmers. It also causes economic losses to organized farming sector because of the ban on the export of live animals, their products and germplasm. Although BT causes asymptomatic infection to large animals such as cattle and buffalo, it may result in significant drop in milk yield and productivity (Tabachnick et al., 1996). Once BTV established in a particular area, it is very difficult to completely eradicate.

\section{BTV genome arrangement}

The BTV particles are non-enveloped, icosahedral, organized in inner core of $75 \mathrm{~nm}$ and outer capsid of $90 \mathrm{~nm}$ in diameter (Nason et al., 2004). The BTV genome consists of 10 segments (L1-L3, M4-M6, S7-S10) of dsRNA, which encode 7 structural (VP1 to VP7) and 4 non-structural (NS1, NS2, NS3/NS3A and NS4) proteins (Mertens et al., 1984; Belhouchet et al., 2011) (Fig. 1a,b). The entire viral genome consists of approximately $19 \mathrm{kbp}$ of nucleotides. The VP1 protein (encoded by segment 1 ) is present in transcription complex and acts as RNA dependent RNA polymerase (Roy et al., 1988). The VP4 and VP6 proteins are also present in transcription complex along with VP1. The VP2 protein (encoded by segment 2) is arranged in trimers to form triskelion motifs on the outer capsid layer of virion. This motif is responsible for receptor binding, hemagglutination and eliciting of serotype-specific neutralizing antibodies (Hassan and Roy, 1999). The VP2 is the major determinant of BTV serotype, with a minor role of VP5. In contrast to VP2, the VP5 protein is significantly more conserved. It shows, however, some degree of variation that reflects the geographic origin of the virus (Singh et al., 2005). The VP5 protein is also arranged as trimers, which form the outer layer globular motifs of BTV particle (Nason et al., 2004). The VP5 protein makes strong contact with underlying layer of VP7 and VP2 proteins. Recent study showed that VP5 has a membrane penetration property, which assists the release of the mature virion from the endosomal compartment to the cytoplasm (Hassan et al., 2001). The highly conserved VP3 protein (encoded by segment 3 ) is an inner most sub-core protein, which forms the icosahedral symmetry of virion (Loudon and Roy 1992). It binds with RNA molecules and 
(a)

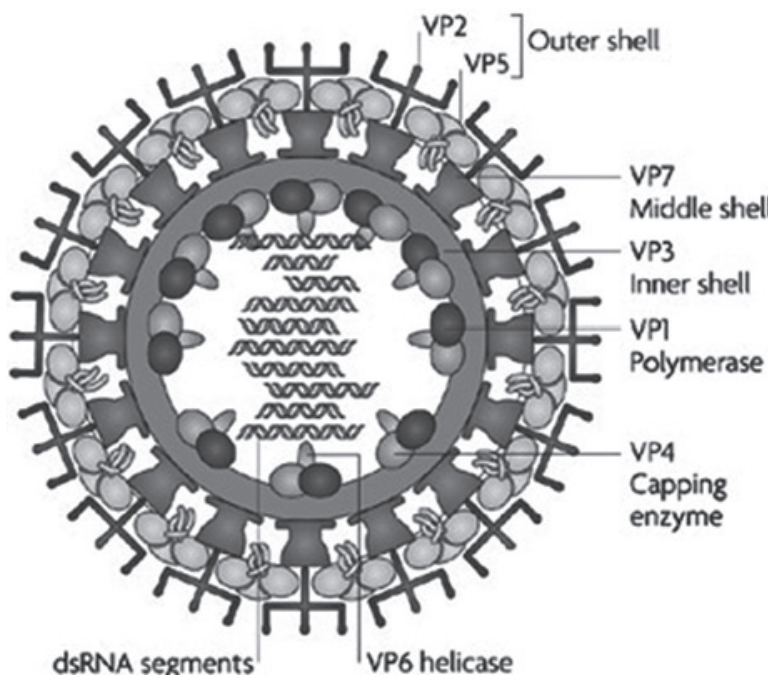

(b)

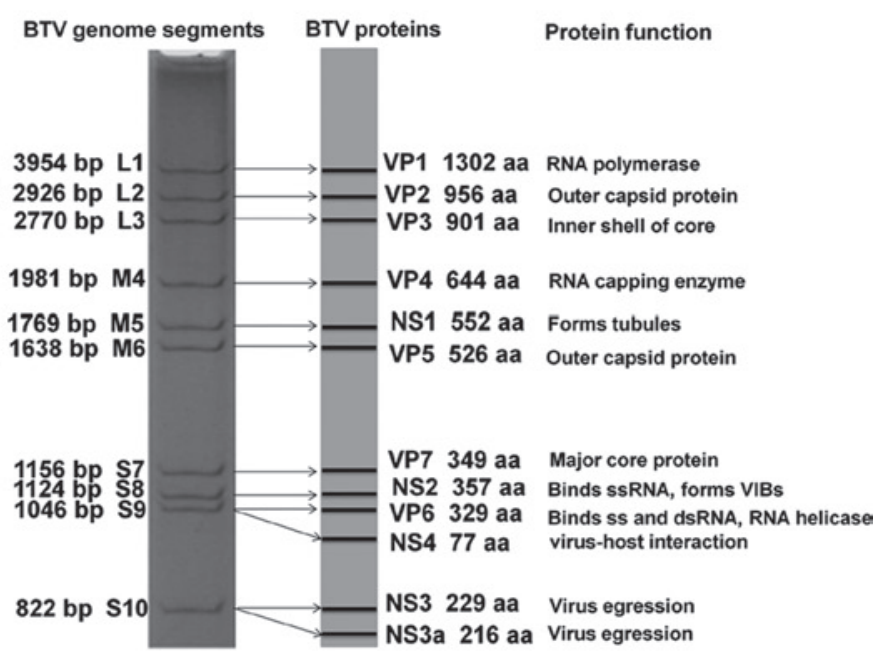

Fig. 1

Bluetongue virus

(a) structure (Roy et al., 2009) and (b) genome segments and their protein function.

transcription complex (VP1, VP4 and VP6). The VP4 protein (encoded by segment 4 ) is a capping enzyme, also known as guanylyltransferase or transmethylase. VP6 is ssRNA- and dsRNA-binding protein with helicase and NTPase activity (Roy et al., 1990). VP7 protein is a serogroup-specific protein present on the outer core surface. BTV-specific non-structural proteins are expressed in infected host cells. They are not present in purified virion particle. The most abundant NS1 protein forms tubules for translocation of progeny virus particles to cell membrane of the infected host cell (Owens et al., 2004). The ssRNA-binding NS2 protein has nucleotidyl phosphatase activity and forms inclusion body in cell cytoplasm (Owens et al., 2004). NS3 and NS3a are smallest non-structural membrane glycoproteins, expressed in insect cells only for release of virion particles from infected cells (Hyatt et al., 1993). Recently, presence of segment 9-encoded NS4 protein in the cytoplasm and nuclei of BTV-infected cells has been reported (Belhouchet et al., 2011).

\section{Susceptibility of Indian sheep breeds to BT}

The sheep population is not uniform in entire India. The highest sheep population density is found in Rajasthan and southern states such as Karnataka, Tamil Nadu, Andhra Pradesh and lowest in the Odisha, Chhattisgarh, Madhya Pradesh and north-eastern states. The BT-specific antibodies have been detected in several domestic and wild ruminants in India (Prasad et al., 2009). However, the clinical form of disease is observed mostly in sheep (Sreenivasulu et al.,
2004). India has several breeds of sheep such as coarse carpet wool breed, apparel quality fine wool breed and mutton breed. The susceptibility of different sheep breeds to BT varies significantly. The European mutton breeds are more susceptible to BT than fine wool breeds. BT entered to India through exotic sheep breeds. Therefore, the initial outbreaks were reported from exotic as well as crossbred animals. Later on, virus got adapted to local sheep population and current BT outbreaks are reported in native sheep breeds (Bommineni et al., 2008; Joardar et al., 2009; Prasad et al., 2009; Reddy et al., 2010; Rao et al., 2012c,d; Susmitha et al., 2012). Higher morbidity, mortality and case fatality rates were observed in Mecheri breed of sheep than in Trichy black and non-descript sheep in Tamil Nadu (Selvaraju, 2014). The Nellore and other non-descript breeds are more susceptible to BT than the Deccani breed in Andhra Pradesh (Rao et al., 2014). The Nellore breed also shows higher mortality rate. The difference in BT susceptibility among these breeds may be due to genetic as well as hair coat differences. The Nellore breed animals have very short hair, whereas Deccani breed has thick coarse wool cover all over the body. Thus short hair pattern of Nellore sheep favors the exposure of the animals to biting midges in comparison to Deccani animals.

\section{Culicoides vectors and BTV infection in India}

Out of more than 1400 different Culicoides species reported worldwide, about 63 are identified from different geographical regions of India such as Assam and West 
Bengal (Dasgupta, 1962; 1995; Halder et al., 2013), Tamil Nadu (Ilango, 2006), Maharashtra (Narladkar et al., 1993), Andhra Pradesh (Reddy and Hafeez, 2008) and Karnataka (Archana et al., 2014). Midges collected from Punjab, Harayana, Himachal Pradesh and Rajasthan were identified as Culicoides oxystoma. The Culicoides species, which transmit BTV in India, are not fully characterized except for few reports on distribution of Culicoides vectors in Gujarat and other north-western states (Bhatnagar et al., 1997; Patel et al., 2007).

Climatic changes and weather conditions significantly affect the Culicoides vectors in India. The morbidity and mortality due to BT disease is also affected by climatic changes and weather conditions. The highest Culicoides population, and consequently maximal annual BT outbreaks, has been recorded in India during monsoon period, i.e. from June to October. Severe BT outbreaks in southern states of India i.e., Karnataka, Tamil Nadu and Andhra Pradesh have also been associated with the monsoon period due to the peak of Culicoides activity (Sreenivasulu et al., 2004). Several species of Culicoides have been identified in Andhra Pradesh state, with predominant species being Culicoides anopheles, Culicoides actoni, Culicoides inoxius, Culicoides peregrines, Culicoides majorinus and Culicoides oxystoma (Reddy, 2004). In contrast, Culicoides species such as Culicoides imicola, Culicoides oxystoma and Culicoides peregrinus, were found as predominant in Tamil Nadu, and Culicoides schultzei in Marathwada region and Kolkata (Dasgupta, 1995). Some other Culicoides species such as Culicoides peregrines, Culicoides schultzei and Culicoides actoni were also reported from the Marathwada region of Maharashtra state (Narladakar et al., 1993). The abundance of Culicoides imicola in Tamil Nadu was also correlated with seroconversions of BT in domestic animals (Ganesh Udupa, 2001). From July 2004 to May 2005 twelve different species of Culicoides, namely Culicoides brevitarsis, Culicoides oxystoma, Culicoides palpisimilis, $\mathrm{Cu}$ licoides imicola, Culicoides perigrinus, Culicoides arakawae, Culicoides circumscriptus, Culicoides homotomus, Culicoides okinawensis, Culicoides similis, Culicoides anophelis and Culicoides azerbajdzhanicus, were identified from a buffalo farm of Bidar district of Karnatka. The species Culicoides oxystoma and Culicoides imicola were reported as predominant (Satheesha et al., 2014).

The evidence of Culicoides involvement in BTV transmission in India was reported for the first time by virus isolation from adult insects in Haryana, although the species of Culicoides was not identified (Jain et al., 1988). Culicoides oxystoma was also identified as vector of BTV in north India, since it was identified at animal farms, where BTVseroconversions were reported (Bhatnagar et al., 1997). Bluetongue virus has also been isolated from a pool of Culicoides (Toxorhynchites splendens) and the virus was detected by fluorescent antibody tests (FAT) and immunoperoxidase test (Rahman and Manickam, 1997). Recently, two isolates of BTV1 (SKN7 and SKN8) were isolated from Culicoides oxystoma vector in Gujarat state (Dadawala et al., 2012).

\section{Bluetongue epidemiology in India}

\subsection{First phase of BT}

The exotic breeds of sheep were imported from USA and South Africa to India during 1960s and 1970s for the genetic improvement of native breeds by crossbreeding. The BT disease was travelled to India along with live animals imported. BT was first reported from Indian subcontinent in 1964 (Sapre, 1964). During 1967 to 1970 the disease was reported in exotic sheep, namely Southdown, Rambouillet, Russian Merino and Corriedale. Severe BT was also reported in the Dorset breed in Andhra Pradesh in 1974. However, the disease symptoms were not reported from the native sheep maintained in close proximity with infected ones. Later on, the disease was recorded in native sheep population from several parts of India. Since 1981, annual BT outbreaks have been reported.

\subsection{Endemic phase of BT}

Although first evidence of BT was seen in India in 1964, BTV could not be isolated from affected animals. The first BTV serotypes to be isolated from affected sheep were serotypes 8 and 18 (Kulkarni and Kulkarni, 1984). Subsequently, serotype 1 was isolated from Rambouillet sheep from Central Sheep Breeding Farm (CSBF), Hisar (Jain et al., 1986). Later on, many other workers reported isolation of different BTV serotypes (BTV2, 3, 9, 16, 18 and 23) from different parts of the country (Prasad et al., 1994; Mehrotra et al., 1996; Sreenivasulu et al., 1999). The presence of BTV-specific antibodies in animals is a major evidence for occurrence of BTV infection (Prasad, 2000). During 1981, BT was widely spread in southern India. The disease was initially detected in Karnataka and in the adjoining regions of Maharashtra and Andhra Pradesh, with mortality rates ranging from $2 \%$ to $50 \%$. A cyclic pattern of the disease was observed with variations in the severity of infection. The BT outbreaks in Maharashtra state were characterized by morbidity, mortality and case fatality rates of $7.66 \%, 1.11 \%$ and $11.82 \%$, respectively (Harbola et al., 1982). Later on, a severe form of BT infection was reported with an overall morbidity, mortality and case fatality rate of $32 \%, 8 \%$ and $25 \%$, respectively, in rural areas of Maharashtra (Kulkarni et al., 1992). The study of BT outbreak pattern in organized farms and rural flocks of Andhra Pradesh state revealed that the pattern of the disease in organized farms and rural flocks is quite different. The higher morbidity and mortality in rural areas was 
attributed to stress factors, such as poor nutrition, parasitic burden, fatigue due to long walks and absence of veterinary facility. Investigations further revealed that sheep aged between 6 to 12 months were more susceptible than adults. The disease has not been reported in lambs (Prasad et al., 2009). Similar observations were reported from Maharashtra and Haryana (Uppal and Vasudevan, 1980; Harbola et al, 1982). Later on, it was reported that sheep were found highly susceptible to BT, with a mortality rate of up to $17.2 \%$, in comparison to cattle and goat (Yasothai, 2013). The BT occurrence in different regions of India varies according to time of rainfall. Maximal numbers of outbreaks were recorded during the north-east monsoon period (October to December) followed by the south-west monsoon period (June to September). In Rajasthan, the outbreaks occurred mostly in September and November (Mahajan et al., 1991). In the Erode District of Tamil Nadu a severe outbreak of BT disease was observed during the month of heavy rainfall (November and December).

\subsection{Recent BT outbreak in India}

The BT outbreaks have been reported from sheep and goat in several states of India. India being endemic for BT, 21 different serotypes of BTV have been reported (Prasad, 2000; Prasad et al., 2009). Recently, however, the 22nd serotype, i.e. BTV21, has been isolated (Table 1) (Susmitha et al., 2012). The serological survey on BTV has indicated the presence of BTV-specific antibodies in Indian sheep, goat, cattle, buffalos, camels and several wild ruminants (Mehrotra et al., 1984; Prasad et al., 1998a; Chandel et al., 2003; De et al., 2009). Several serotypes of BTV have been isolated from the regions where sheep population is higher. The north-western region of the country is mostly affected with BTV1. The BTV1 has been isolated from sheep, goat and Culicoides vector in this region (Jain et al., 1986, 1988; Prasad et al., 1994; Biswas et al., 2010). BTV23 has been reported from Uttarakhand, Madhya Pradesh, Maharashtra, Karnataka, Jammu and Kashmir (Mehrotra et al., 1995, 1996; Tembhurne et al., 2010). The BTV-specific antibodies in small ruminant have been reported from Delhi. The Agar Gel Immunodiffusion (AGID) test showed an overall seropositivity of $13.21 \%$ for BTV in non-descript goat from Delhi (Audarya et al., 2015). The BTV serotype 1 (isolate PTG-13) from goats in the Pithoragarh area of Uttarakahand has also been isolated (Mondal et al., 2013).

During 2005-2009, the serotype-specific serum-neutralization test for BTV in Andhra Pradesh, showed 50.0, 44.23, $21.15,26.92$ and $15.38 \%$ seroprevalence of BTV serotypes 1, 2, 9, 10 and 23, respectively (Sairaju et al., 2013). The BTV2, BTV9 and BTV15 have been reported from sheep in the Andhra Pradesh state (Sreenivasulu et al., 1999; Bommineni et al., 2008; Balam et al., 2011). The serological survey using dot ELISA and competitive ELISA (C-ELISA) techniques confirmed the BTV prevalence in Kerala state (Ravishankar et al., 2005). The overall BT seroprevalence has increased to 9.3\% in domestic ruminants in Kerala (Arun et al., 2014). High seroprevalence of BT in sheep, goat and cattle has also been reported in the northeast region (Assam). However, the live virus could not be isolated (Joardar et al., 2013). The serological study also confirmed the high prevalence (86\%) of BTV in Mithun (Bos frontalis) in Northeast region (Nagaland state) of India (Rajkhowa et al., 2008). The serotypes BTV15 and BTV21 have been isolated from sheep in eastern part of India (West Bengal) (Joardar et al., 2009). Globally, all BT viruses can be divided into eastern and western topotype based on geographic origin of the virus (Gould, 1987; Maan et al., 2008). Both eastern and western topotypes of BTV have been isolated from different region of India. The trade of livestock and their products along with live attenuated vaccine from western countries has played a major role in occurrence of western BTV genome segments in India (Rao et al., 2012a). The eastern topotype BTV1 (Maan et al., 2012a) and western topotype BTV2 and BTV10 (Maan et al., 2012b,c) have been reported recently. The complete genome sequence of a reassortant strain of BTV16 of goat origin from India has been obtained recently (Minakshi et al., 2012). Moreover, BTV serotype 1 from Culicoides oxystoma vector in Gujarat state and serotype 10 from Andhra Pradesh have been isolated (Dadawala et al., 2012; Prasad et al., 2013).

The Indian isolates of BTV show a great degree of reassortment between different serotypes and also between eastern and western topotype viruses within same serotype. Multiple serotypes of BT viruses are circulating in a geographical area,

Table 1. Bluetongue virus prevalence in India (Prasad et al., 2009, modified and updated)

\begin{tabular}{lll}
\hline State & $\begin{array}{l}\text { BTV serotypes based } \\
\text { on the neutralizing } \\
\text { antibodies }\end{array}$ & $\begin{array}{l}\text { BTV serotypes based } \\
\text { on the virus isolation }\end{array}$ \\
\hline Jammu and Kashmir & - & 23 \\
Himachal Pradesh & 4 & $3,4,9,16,17$ \\
Haryana & $2,8,12,16$ & 1,4 \\
Rajasthan & - & 1 \\
Uttar Pradesh & 23 & $1,9,18,23$ \\
Uttrakhand & - & 23 \\
Madhya Pradesh & 18,23 & 23 \\
Gujarat & $1,2,3,5,8,9,10,11,12,1,6,16$ \\
Maharashtra & $13,15,16,17,20$ & \\
& $2,3,4,5,6,7,8,10,12,1,9,16,18,4,17$ \\
Andhra Pradesh & $4,6,16$ & \\
Karnataka & 19 & $1,2,4,12,16,17,20$ \\
Tamil Nadu & $1,3,4,5,6,7,11,12,14,1,2,3,16,23$ \\
& $15,16,17,19,20$ & \\
\hline
\end{tabular}


which leads to infection of individual animals and herds with more than one serotype. It facilitates the exchange of genetic material between different viruses and evolution of new reassortant strains of BTV (Reddy et al., 2015). A reassortant strain of BTV16 having segment 5 (ns1 gene) of western origin and other segments of eastern origin has been reported from Andhra Pradesh state (Kumar et al., 2013). The eastern-western reassortant strains of several BTV serotypes such as BTV2, BTV3, BTV23, BTV9, BTV1 and BTV12 have also been reported from India (Maan et al., 2012d,f; Rao et al., 2012b,c,d; 2013a,b).

\section{Phylogenetic analysis and sequence diversity of Indian BTV isolates}

The whole-genome-sequence-based phylogenetic analysis is essential to understand the origin of a virus. However, the antigenic protein gene vp2 and vp5 (segment 2 and 6) and group-specific conserved protein gene vp3 and vp7 (segment 3 and 7) are most commonly used for phylogeny and molecular epidemiology. A large number of partial as well as complete gene sequences of several isolates of different BTV serotypes were obtained. The phylogenetic analysis of individual gene segments of Indian isolates of BTV reveals its genetic relationship with global isolates.

\section{Segment 1}

Segment 1 (vp1 gene) codes for highly conserved VP1 protein, which acts as RNA polymerase. The complete gene sequence-based phylogenetic analysis showed both eastern and western origin of segment 1 of Indian BTV isolates (Fig. 2a and S1). Indian isolates of BTV1 (K23/08), BTV2 (IND1982/01), BTV3 (IND2003/08), BTV9 (IndR1-2007), BTV16 (IND/Goat/2010/16/HSR) and BTV23 (IND1988/02) are closely related (>80\% identity) with major eastern topotype of BTV 16 (isolate 5268/5) and BTV23 (isolate 7766) from South Africa (Maan et al., 2015). Similarly, Indian BTV1 (IND1992/01) was found closely associated with eastern BTV2 from Australia. The BTV9 (BBF) and BTV12 (INDAPADBNMO1/11) were closely related with eastern virus BTV9 from Italy (Fig. $2 \mathrm{a}$ and $\mathrm{S} 1$ ). Further, segment 1 of BTV2 (IND2003/02) and BTV10 (IND2004/01) was found identical to western vaccine strain of BTV2 and BTV10 from South Africa and USA respectively (Maan, 2012c; Maan et al., 2015). It indicates that these viruses might originate from a vaccine strain.

\section{Segment 2}

Segment 2 (vp2 gene) codes for major serotype-specific antigenic VP2 protein. Most of the Indian BTV1 isolates originate from Australian viruses and are of eastern topotype in origin. The phylogenetic study of segment 2 of Indian BTV1 isolates showed more than $99.6 \%$ nucleotide identity among themselves. However, phylogenetic analysis of segment 2 of one of the Indian isolate of BTV1 isolate MKD18 revealed $86.3-86.8 \%$ nucleotide identity with Australian BTV1 isolates (Biswas et al., 2010). The partial vp2 gene sequence analysis of Indian BTV1 isolates revealed 79-89\% identity between Indian and Australian isolates and only 73-75\% identity with South African isolates (Dahiya et al., 2004). Similarly, the phylogenetic comparison of segment 2 of some of the Indian BTV1 isolates from Rajasthan and Gujarat state form a monophyletic group with Australian BTV1 isolates, showing its eastern origin (Bisht et al., 2011; Maan et al., 2012a; Chauhan et al., 2014). The segment-2based phylogenetic analysis of some of the Indian BTV16 isolates of goat origin showed a close resemblance with Japanese and Greek isolates than with Australian isolate of BTV16 serotype (Dadawala et al., 2013). The phylogenetic and restriction enzyme analysis of vp2 gene of an Indian BTV2 isolate showed close relationship to the Taiwan isolate (Balumahendiran et al., 2009).

The segment 2 sequences not only form distinct clads within serotype (topotype), but several distinct serotypes cluster more closely together and are identified as nucleotypes. The phylogenetic analyses of complete gene sequence of segment 2 classify BTVs in 10 nucleotypes (A-J) (Maan et al., 2010). Indian isolate of BTV10 was placed within A, BTV3 and 16 in B, BTV21 in C, BTV23 in D, BTV2 in I, BTV9 in E, BTV12 in G and BTV1 in nucleotype H (Fig. 3a and S2). Segment 2 of Indian isolates of BTV1 (IND1992/01 and K23/08), BTV3 (IND2003/08), BTV9 (BBF and IndR1-2007), BTV12 (INDAPADBNMO1/11), BTV16 (IND/ Goat/2010/16/HSR and Vjw/64/08/IND), BTV21 (Kmno7/06/IND) and BTV23 (IND1988/02) showed $>90 \% \mathrm{nu}-$ cleotide identity with eastern topotype viruses of the same serotype (Maan et al., 2012a, 2015; Minakshi et al., 2012; Rao et al. 2012d; 2013a,b; Shafiq et al., 2013). However, segment 2 of some of the Indian BTV serotypes shows both eastern as well as western topotype origin. The earlier Indian isolates of BTV2 (IND1993/01 and IND1994/01) showed eastern, while the later isolates (IND2003/02) showed western topotype origin of segment 2 . The segment 2 of western strain showed $>99 \%$ nucleotide identity with vaccine strain of BTV2 from South Africa (Maan et al., 2015). The segment 2 sequence of an Indian BTV10 isolate (IND2004/01) was grouped with vaccine strain of BTV10 (Acc. no. U06786) from USA within major western topotype (Maan, 2012c). It suggests that some of the Indian BTV could have been imported from USA.

\section{Segment 3}

Segment 3 (vp3 gene) codes for VP3 protein, which forms core of the virus along with VP7 protein. Despite a higher degree of sequence conservation, segment 3 shows significant level of variation, which reflects the geographic origin of BTV. The restriction enzyme analysis 

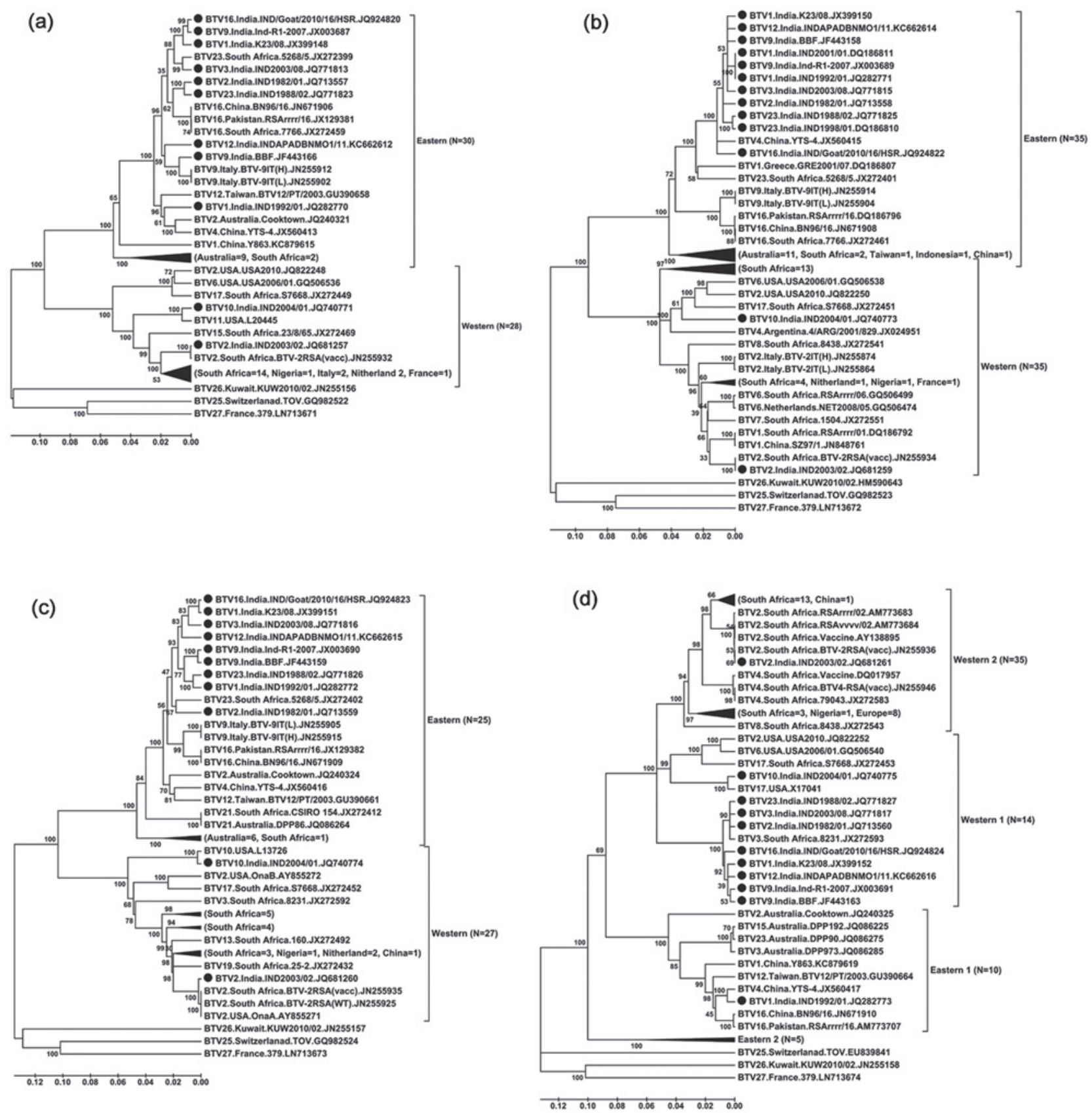

Fig. 2

Neighbor-joining phylogenetic tree of (a) Segment 1, (b) Segment 3, (c) Segment 4 and (d) Segment 5 of BTV isolates from around the world Phylogenetic tree was generated using p-distance determination algorithm and bootstrap value of 1,000 replicates in MEGA5 software (Tamura et al., 2011). $\mathrm{N}=$ number of $\mathrm{BTV}$ isolates, $\bullet=$ Indian BTV isolates.

and phylogenetic study revealed certain degree of genetic variation in segment 3 of Indian BTV isolates (Prasad et al., 2011). It classifies individual BTV isolates into eastern and western topotypes along with a number of further sub-groups (Pritchard et al., 1995). Therefore, vp3 gene sequence comparison can be used as a way to identify the geographical origin (different topotypes) of BTV isolates. The phylogenetic analysis of complete sequence of segment 3 revealed that majority of the Indian BTV isolates of BTV1 (isolate K23/08, IND2001/01 and IND1992/01), BTV2 
(IND1982/01), BTV3 (IND2003/08), BTV9 (BBF and Ind-R1-2007), BTV12 (INDAPADBNMO1/11), BTV16 (IND/Goat/2010/16/HSR) and BTV23 (IND1988/02 and IND1998/01) showed $>79 \%$ nucleotide identity with eastern viruses from South Africa, Australia and Europe and placed in eastern topotype (Maan et al., 2012a; 2015; Minakshi et al., 2012; Rao et al. 2012d, 2013a,b). However, segment 3 of BTV2 (IND2003/02) was closely related with western topotype vaccine strain from South Africa (BTV2RSA(vacc)) (Fig. 2b and S3). The BTV10 (IND2004/01) was grouped with major western topotype viruses BTV10, 11, 13 and 17 from USA (Maan et al., 2015).

\section{Segment 4}

Segment 4 (vp4 gene) codes for highly conserved capping enzyme, which is a minor component of the BTV core particle. It also has transmethylase activity. Phylogenetic study of segment 4 also separates BTV in two distinct groups, i.e. eastern and western topotype (Figure $2 \mathrm{c}$ and S4). The segment 4 of Indian BTV1, 2, 3, 9, 12, 16 and 23 are of eastern origin (Maan et al.,2012a, 2015; Minakshi et al., 2012; Rao et al.2012d;2013a,b), whereas BTV2 (IND2003/02) and BTV10 (IND2004/01) were placed within western topotype group (Maan et al., 2015).

\section{Segment 5}

Segment 5 (ns1 gene) codes for relatively conserved and virus group-specific NS1 (non-structural) protein. It can be used for detection of bluetongue virus from clinical samples. The ns1 gene of Indian BTVs showed a higher degree of reassortment in eastern and western topotype viruses. A reassortant strain of BTV16 (VJW64) having segment 5 of western and segment 2 and 6 of eastern origin was reported from Andhra Pradesh state (Kumar et al., 2013). Moreover, phylogenetic analysis of complete genome sequence showed reassortment in segment 5 of several Indian BTVs (Fig. 2d and S5). The segment 5 of BTV1 (K23/08), BTV3 (IND2003/08), BTV9 (Ind-R1-2007 and BBF), BTV12 (INDAPADBNMO1/11), BTV16 (IND/Goat/2010/16/HSR) and BTV23 (IND1988/02) belong to western 1 topotype, whereas remaining segments are of eastern topotype (Maan et al., 2012d, f; Minakshi et al., 2012; Rao et al., 2013a, b). All genome segments of two Indian viruses, BTV10 (IND2004/01) and BTV2 (IND2003/02) were grouped within western topotype and characterized as pure western topotype virus. The segment 5 of these isolates was placed in western 1 and western 2 topotypes, respectively, and showed maximum identity with vaccine strains from USA and South Africa (Maan et al., 2012b; 2012c). Similarly, BTV1 (IND1992/01) was demonstrated as pure eastern topotype virus. The segment 5 of BTV1 (IND1992/01) was placed in eastern 1 topotype along with viruses from China, Pakistan and Taiwan (Maan et al., 2012a). Recently, it was observed that several Indian BTV isolates acquired segment 5 of western origin while other segments remain eastern topotype. The
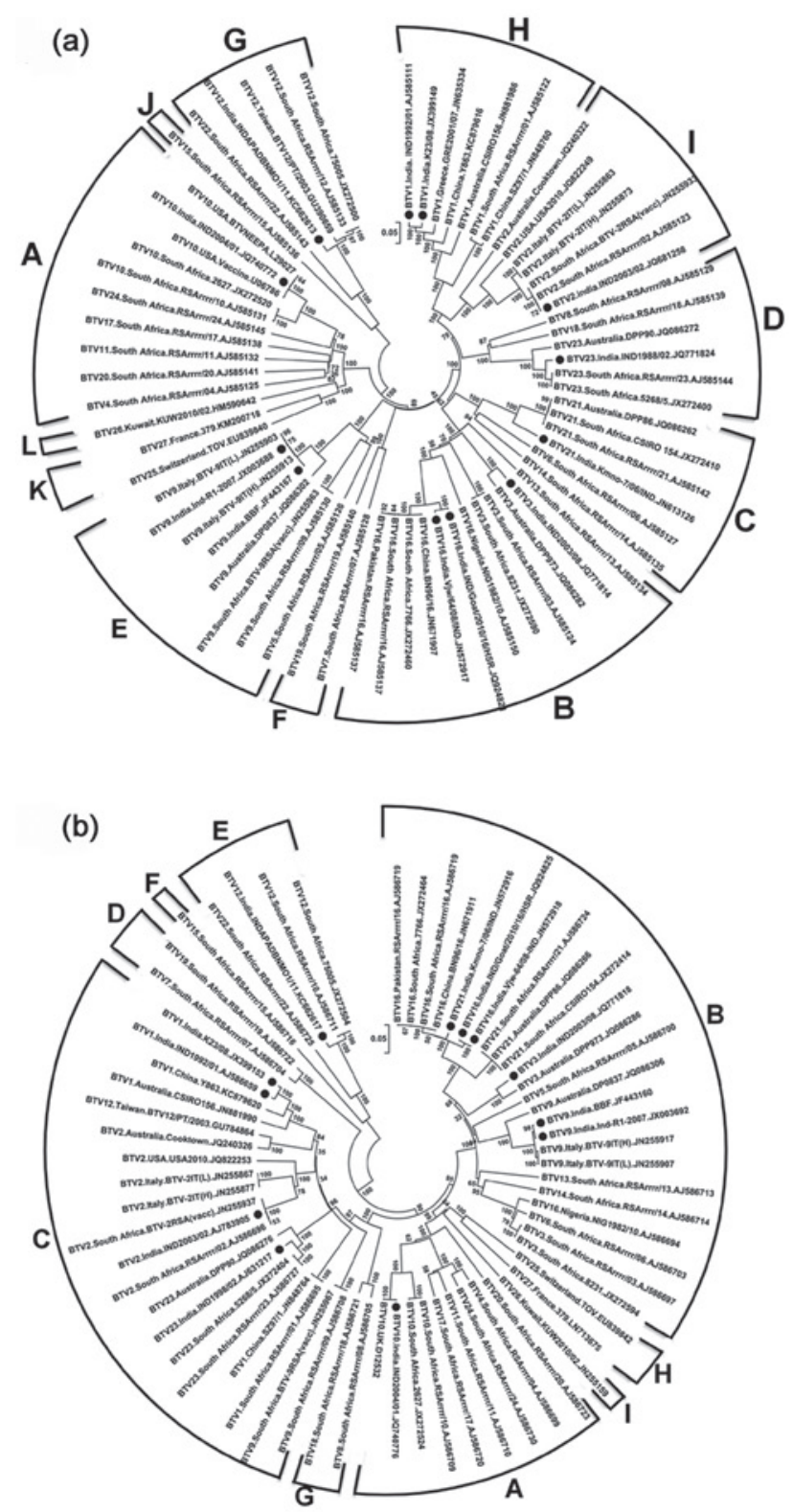

Fig. 3

Neighbor-joining phylogenetic tree of (a) Segment 2 and (b) Segment 6 of BTV isolates from around the world

Phylogenetic tree was generated using $\mathrm{p}$-distance determination algorithm and bootstrap value of 1,000 replicates in MEGA5 software (Tamura et al., 2011). $\bullet=$ Indian BTV isolates.

western segment 5 can be temporally correlated with recent BT outbreaks and an increase in virus virulence in India.

\section{Segment 6}

Segment 6 (vp5 gene) codes for minor VP5 protein, which is indirectly involved in induction of immune response. It enhances the virus neutralization activity of VP2 protein and 
induces higher antibody titer than VP2 protein alone. The phylogenetic analyses of complete gene sequences of segment 6 of all 27 BTV serotypes classify them into 9 distinct (A-I) nucleotypes. Indian viruses of BTV10 serotype are placed in nucleotype A, BTV3, 9, 16 and 21 in nucleotype B, BTV1, 2, and 23 in C and BTV12 in nucleotype E (Fig. $3 \mathrm{~b}$ and S6). The reference strain BTV 9 from South Africa (RSArrrr/09) was originally placed in nucleotype C along with BTV serotypes 1, 2, and 23 (Maan et al., 2010). However, Indian BTV9 isolates (Ind-R1-2007 and BBF) were placed in nucleotype B along with BTV9 from Italy (BTV-9IT $(\mathrm{H})$ and BTV-9IT(L)) and Australia (DP0837) and BTV3,5, 6, 13, 14, 16 and 21 from different regions of the world (Fig. $3 \mathrm{~b}$ and S6). It also indicates the genomic diversity in segment 6 of BTV9 from India and other countries. The segment-6-based analyses of Indian BTVs also showed the eastern and western topotype origin. Segment 6 of Indian isolates of BTV2 (BT2) and BTV9 (Ong5/06/Ind) showed western origin (Ranjan et al., 2013, 2014a), whereas BTV16 (BT16/07) and BTV1 showed eastern origin (Ranjan et al., 2014b; Manjunatha et al., 2010). Moreover, Indian viruses BTV1 (IND1988/0 1), BTV3 (IND2003/08), BTV9 (IND2005/01), BTV16 (IND/ Goat/2010/16/HSR), BTV21 (Kmno-7/06/IND) and BTV23 (IND1988/02) were grouped as eastern topotype with $>77.1 \%$ identity with previously characterized homologous serotypes of eastern origin (Maan et al., 2015). The vp5 gene of some of the Indian BTV isolates such as BTV10 (IND2004/01) and BTV12 (INDAPADBNMO1/11) were confirmed as western topotypes. They showed maximum nucleotide identities with USA vaccine strain and BTV12 from South Africa, respectively (Maan et al., 2012c; Rao, et al, 2013b). However, the segment 6 of Indian BTV2 was both of eastern and western topotype origin. The earlier isolated BTV2 (IND1982/01) contains an eastern segment 6, while newer BTV isolates (IND2003/01, IND2003/02 and IND2003/03) carry this segment of western origin. Moreover, a higher degree of reassortment in segment 6 was also reported. The segment 6 of south Indian isolates of BTV2 (IND1993/01 and IND1994/01) was found identical to Indian BTV1 strains (IND2003/05) (Maan et al., 2015). Similarly, a reassortant strain of BTV21 (isolate KMNO-7) having segment 6 of BTV16 has been reported from Andhra Pradesh state (Shafiq et al., 2013).

\section{Segment 7}

Segment 7 (vp7 gene) codes for major core protein VP7. The complete vp7-gene-sequence-based phylogenetic analysis classifies all BTV isolates in 4 western and 3 eastern topotypes (Fig. 4a and S7). The segment 7 of Indian isolate of BTV10 (IND2004/01) and BTV12 (INDAPADBNMO1/11) was placed in western 1 topotype along with viruses from South Africa, USA, Netherlands, France and China. The BTV2 (IND2003/02) was placed in western 2 topotype. Several BTV isolates from India BTV1 (IND1988/01, IND1992/01, Avikanagar, K23/08, Sirsa S1 and Sirsa S3), BTV2 (IND1982/01, IND1982/01), BTV18 (Bangalore) and BTV23 (IND1988/02, Rahuri and Dehradoon) were placed in Eastern 2 topotype along with other eastern viruses from South Africa, China, Australia (Kataria et al., 2006; Kovi et al., 2006; Dalal et al., 2009; Rao et al., 2013a; Maan et al., 2012a, 2015). Moreover, Indian BTV3 (IND2003/08), BTV9 (Ind-R1-2007 and BBF) and BTV16 (IND/Goat/2010/16/HSR) were reported in Eastern 3 topotype along with other eastern viruses from Pakistan, South Africa, Australia and Italy (Maan et al., 2012e; Minakshi et al., 2012; Rao et al., 2012c). The phylogenetic analysis also suggests that vp7-gene-based grouping of Indian BTV isolates is random and it does not assort according to serotype, even over distant geographical location.

\section{Segment 8}

Segment 8 encodes the highly conserved NS2 protein expressed in virus-infected host cell. It assists in viral inclusion body formation. Phylogenetic analysis of segment 8 sequences separates Indian BTV isolates in eastern and western topotypes (Fig. 4b and S8). Indian isolates of BTV2 serotype (IND2003/01, IND2003/02 and IND2003/03) showed $>99 \%$ identity with South African vaccine isolate (BTV-2RSA (vacc)) and clustered in major western topotype (Maan et al., 2015). Similarly, Indian isolates of BTV10 (IND2004/01) and BTV23 (IND1997/01) were grouped under western topotype viruses with $>99 \%$ nucleotide identity (Maan et al., 2012c). Some of the Indian isolates of BTV1 (K23/08 and IND1992/01), BTV2 (IND1982/01), BTV3 (IND2003/08), BTV9 (BBF, IND2005/02, Ind-R1-2007 and IND2005/01), BTV12 (INDAPADBNMO1/11), BTV16 (IND/Goat/2010/16/HSR and IND2004/05) and BTV23 (IND2004/08 and IND1988/02) are classified under major eastern topotype along with previously characterized viruses from China, Pakistan, Taiwan and South Africa (Maan et al., 2008, 2012d,f; Minakshi et al., 2012; Rao et al., 2013a,b).

\section{Segment 9}

BTV segment 9 encodes the two conserved proteins: VP6 (helicase) and NS4. The segment-9-based analyses also classify Indian BTV isolates in eastern and western topotype (Fig. 4c and S9). Segment 9 of Indian isolates of BTV2 (IND2003/02) and BTV10 (IND2004/01) serotypes was suggested as recent western ancestry since they were very close to the USA isolate within the western topotype viruses. Majority of Indian BTV isolates were classified under eastern topotype, irrespective of their serotype. The segment 9 of an Indian BTV12 isolate (INDAPADBNMO1/11) was grouped with Asian/Australian isolates. However, it was found more closely related to Australian and Taiwanese isolates than to Indian isolates (Rao et al., 2013b; Maan et al., 2015). Indian BTV23 isolates (IND1988/02 and IND1997/01) share 99.9\% 


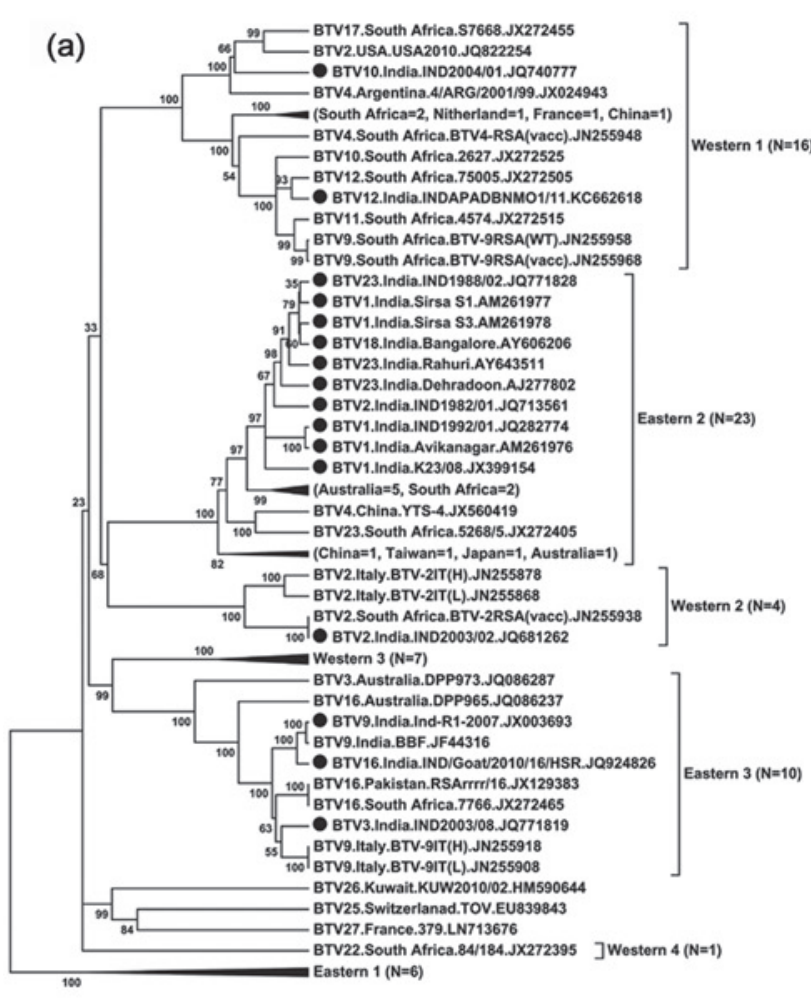

$\begin{array}{llllllll}0.12 & 0.10 & 0.08 & 0.06 & 0.04 & 0.02 & 0.00\end{array}$

(c)

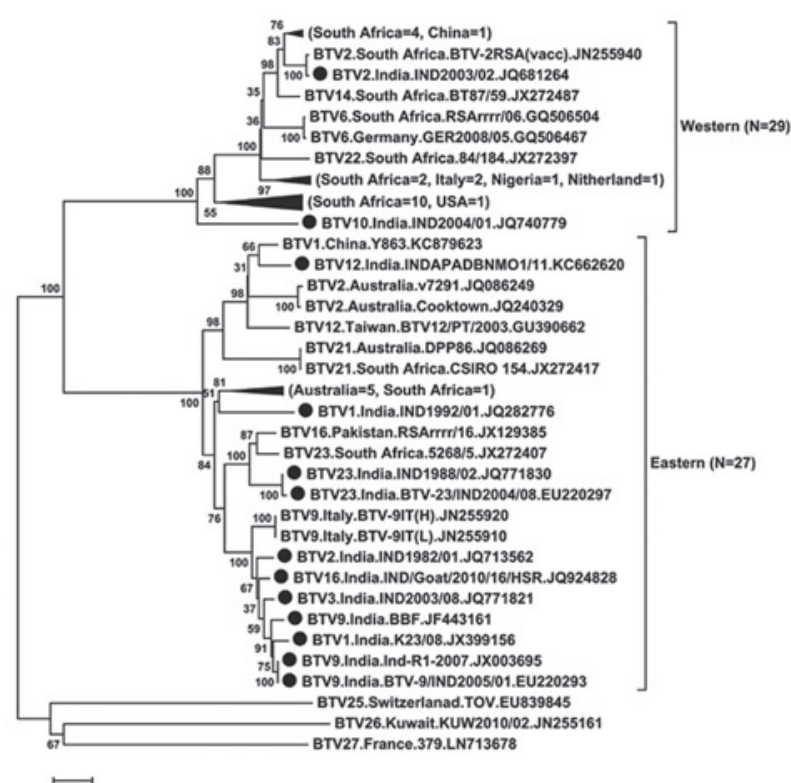

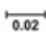
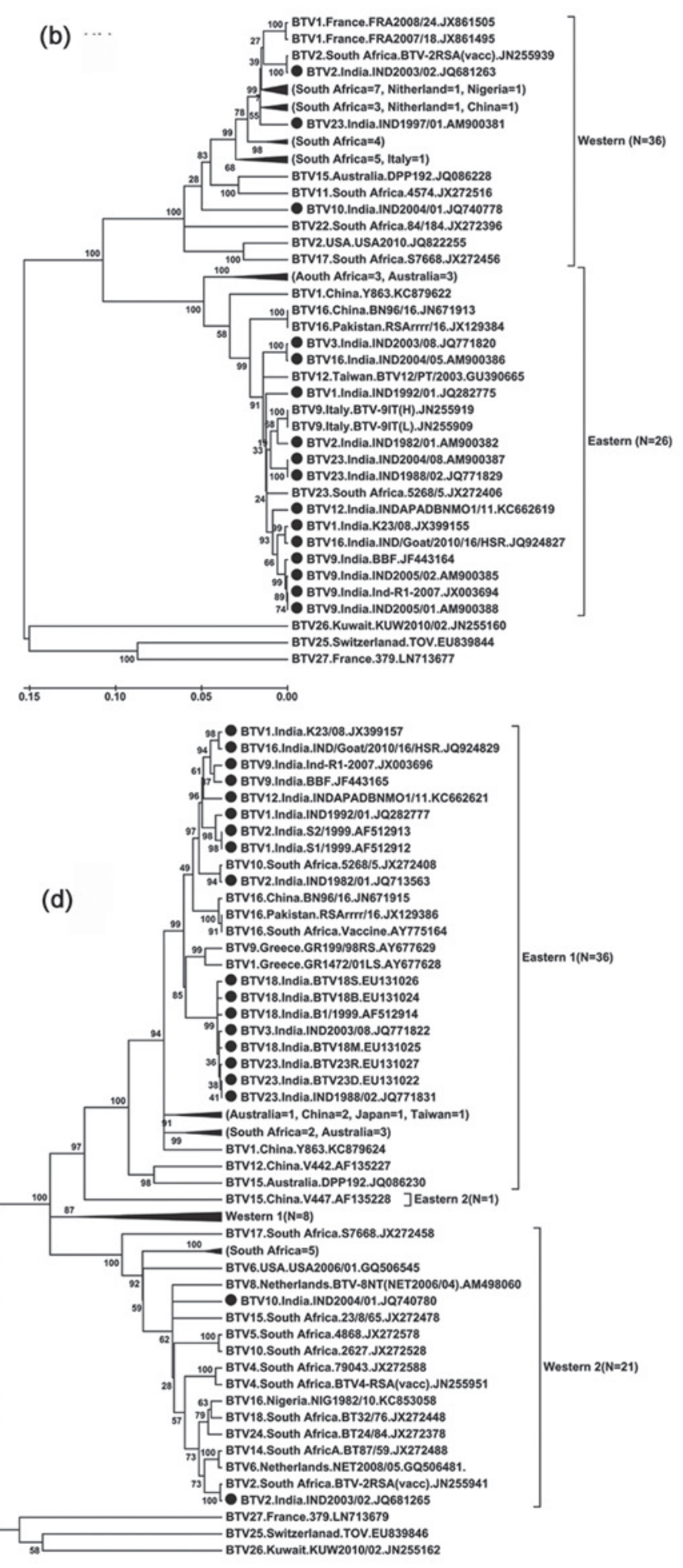

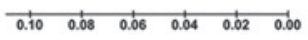

Fig. 4

Neighbor-joining phylogenetic tree of (a) Segment 7, (b) Segment 8, (c) Segment 9 and (d) Segment 10 of BTV isolates from around the world Phylogenetic tree was generated using p-distance determination algorithm and bootstrap value of 1,000 replicates in MEGA5 software (Tamura et al., 2011). $\mathrm{N}=$ number of $\mathrm{BTV}$ isolates, $\bullet=$ Indian BTV isolates. 
to $100 \%$ sequence identity with BTV1 (IND2003/10) in segment 9 , indicating a recent common and eastern ancestry (Maan et al., 2015). Segment 9 of several other Indian viruses, BTV1 (K23/08 and IND1992/01), BTV2 (IND1982/01), BTV3 (IND2003/08), BTV9 (BBF, Ind-R1-2007 and BTV-9/ IND2005/01), BTV16 (IND/Goat/2010/16/HSR) and BTV23 (BTV-23/IND2004/08) showed maximum nucleotide identity with eastern viruses and placed in eastern topotype (Fig. 4c and S9).

\section{Segment 10}

The segment 10 codes for NS3 and NS3A proteins, which participate in virus egress from infected host cells. The segment-10-based phylogenetic analyses are important for understanding the BTV evolution. The partial gene sequence analysis revealed that Indian isolates BTV 18 and 23 were closer to each other and form a close cluster with BTV from China, Indonesia and Australia (Desai et al., 2009). Moreover, the complete-gene-sequence-based phylogenetic analysis of segment 10 classified the Indian isolates of BTV1 (K23/08, IND1992/01 and S1/1999), BTV2 (S2/1999 and IND1982/01), BTV3 (IND2003/08), BTV9 (Ind-R12007 and BBF), BTV12 (INDAPADBNMO1/11), BTV16 (IND/Goat/2010/16/HSR), BTV18 (BTV18S, BTV18B, B1/1999 and BTV18M) and BTV23 (BTV23R, IND1988/02, BTV23D) within eastern 1 topotype and were closer to viruses from Pakistan, China, Greece and South Africa (Fig. $4 \mathrm{~d}$ and S10). Indian isolate of BTV2 (IND2003/02) showed $>99 \%$ nucleotide sequence identity with South African vaccine strain of BTV2 (BTV-2RSA(vacc)) and placed within western 2 topotype. Similarly, Indian virus BTV10 (IND2004/01) was also grouped in western 2 group.

The phylogenetic analysis of complete genome sequence revealed that most of the genome segments of Indian BTV isolates (BTV1, 2, 3, 9, 16, 21 and 23) group within major eastern topotype indicating that they might originate either from India or Australia and eastern Asian region (Maan et al., 2010). However, segment 5 of most of these isolates was placed within western topotype. Later on, some vaccine-virus-derived pure western BTV strains were isolated from India. Indian BTV2 (IND2003/02) and BTV10 (IND2004/01) isolates show $>99 \%$ nucleotide identity with live attenuated vaccine strains of BTV2 and BTV10 from South Africa and USA, respectively. These viruses entered to India either through import of live vaccinated animals or live vaccine itself. Several BTV serotypes such as BTV1-6 and 10 were associated with clinical disease in sheep and considered as high risk for epidemic outbreak in South Africa. To control BT in South Africa, multivalent live attenuated vaccine (containing BTV3, 2, 4, 8-11, 16) had been developed and used. These vaccines were simultaneously used also in Bulgaria, Spain, Italy, Portugal, France, Israel, Iberian Peninsula and eastern Mediterranean Islands (Dungu et al., 2004a; Savini et al., 2008; Zientara et al., 2010; Coetzee et al.,
2012). Similarly, several BTV serotypes such as BTV 10, 11, 13 and 17 were reported in USA by intensive disease surveillance. The prototype BTV10 strain was used for live vaccine preparation (Osburn et al., 1981; Fukusho et al., 1989). Several sheep breeds such as Rambouillet from America, Dorset, Corriedale and Merino from Australia were imported to central sheep breeding farm (CSBF) Hisar, India during late 1970s and 1980s (Prasad et al., 2009; Jain et al., 1986). Similarly, cattle were also imported from USA, Belgium, Germany, France, South Africa, Russia, Thailand and UK during 2002 to 2005 (Rao et al., 2012a). The live attenuated vaccines against BTV have been used in some of these countries during this period. Moreover, it is also possible that western topotype live attenuated vaccines have been imported to India despite trade restriction. The live vaccines cause significant levels of post vaccination viremia, which leads to virus transmission by Culicoides during blood feeding. Later on live vaccine viruses might be reverting to a virulent strain because of different vector and environmental conditions (Batten et al., 2008; Veronesi et al., 2010). However, the fate of these exotic viruses may vary. They may either persist as intact western topotype (BTV2 and BTV10) for a while or may contribute individual western genome segment (segment 5) to other indigenous viruses.

\section{Differential diagnosis}

The clinical signs of BT resemble other ruminant diseases. Thus, BT can easily be confused with other ruminant diseases such as foot-and-mouth disease, vesicular stomatitis, peste des petits ruminants, photosensitisation, pneumonia, akabane infection, contagious ecthyma, polyarthritis, footrot, plant poisoning, coenurosis, facial eczema, sheep pox, oestrus ovis infestation, malignant catarrhal fever, pododermatitis, infectious bovine rhinotracheitis, bovine herpes mamillitis, bovine viral diarrhea, bovine popular stomatitis, epizootic hemorrhagic disease, etc. (Mehlhorn et al., 2008; Williamson et al., 2008; Savini et al., 2011). BTV may infect animals along with other viruses, which usually show similar symptoms, making the diagnosis difficult. The mixed infection of BTV along with peste des petits ruminants virus (PPRV) in goat flock was identified by antigen-, antibody- and nucleic-acid-based methods (Mondal et al., 2009). Therefore, confirmatory diagnosis of BT in ruminants should be done by clinical symptoms of the disease along with various sensitive molecular biological tools.

\section{Diagnosis}

The BT is tentatively diagnosed based on clinical profile of the disease, pathological lesions along with the knowledge of the disease epidemiology including vector distribution, sus- 
ceptible host population etc. Various biological samples such as blood, serum, aborted fetus, placenta, infected chicken embryos, cell cultures, mononuclear cells, Culicoides vectors are used for BTV identification (Chander et al., 1991; Garg and Prasad, 1994, 1995; Dadawala et al., 2012). The definitive diagnosis of BTV is done mainly by serological tests, virus isolation either in chicken embryo or cell culture, and detection of viral nucleic acid.

\subsection{Virus isolation}

The virus isolation from a clinical sample is the most conventional way of confirmatory diagnosis of BT disease. A number of virus isolation systems such as embryonated hen's egg and cell culture are in use for BTV isolation. The virus particles isolated may be confirmed either by molecular, immunological or electron microscopy tests. Suspected biological materials are homogenized in PBS or isotonic saline and inoculated in 9-12 days old embryonated chicken egg. Embryos die 2 to 7 days after inoculation, showing characteristic embryopathic hemorrhagic lesions. After primary isolation of BTV in embryonated hen's egg the subsequent passage is performed in $\mathrm{C} 6 / 36, \mathrm{BHK}-21$ or Vero cells. BTV can be identified in BHK-21 cell culture by a characteristic cytopathic effect (CPE), such as foamy degeneration, aggregation and floating of dead cells within 2-5 days after infection. In India, embryonated chicken eggs (ECE), BHK-21 cells and mosquito cells (C6/36) have been used for the isolation and characterization of BTV (Kulkarni and Kulkarni, 1984; Jain et al., 1986; Mehrotra et al., 1995; 1996; Ranjan et al., 2013, 2014b).

\subsection{Immunological detection of the virus}

Several immunological assays such as immunofluorescence, immunoperoxidase labeling, AGID, ELISAs and dot immunobinding assays (DIA) have been used for detection of BTV. High prevalence of BTV antibodies by AGID test in sheep, goats, cattle, buffalo and in camel sera has been reported through epizootiological survey carried out in northern states of country including Haryana, Punjab, Rajasthan, Himachal Pradesh and Jammu \& Kashmir (Prasad et al., 1987; Malik et al., 2002). Prevalence of BT group-specific antibodies was reported in elephants, black bucks and spotted deer in Tamil Nadu (Narayana and Manicham, 1997). The BTV-specific antibodies in domestic and wild ruminants in and around Sariska Tiger Reserve, Rajasthan were detected using AGID Test (Prasad et al., 1998a).

VP7-specific monoclonal antibody and baculovirus-expressed VP7 protein as antigen were used for standardization of BTV serogroup-specific C-ELISA, blocking ELISAs and DIA (Naresh and Prasad, 1995; Naresh et al., 1996). Out of several other serological tests, such as AGID, the C-ELISA assay was found most specific and sensitive in detection of BTV-specific antibody in camel serum (Chandel et al., 2003). The VP7-protein-based C-ELISA showed 28.6\% seroprevalence of BTV in sheep and goat in Uttar Pradesh state (Bitew et al., 2013). Serological survey using recombinant viral protein 7 (rVP7) in indirect ELISA showed $47 \%$ of serological prevalence of BTV in goats of the Sunderban area of West Bengal state (De et al., 2009). Recently, a combined indirect enzyme-linked immunosorbentassay (CI-ELISA) was developed, which can detect antibodies against bluetongue virus and peste-des-petits-ruminants virus simultaneously (Yousuf et al., 2015).

\subsection{Nucleic-acid-based diagnosis}

The recent advance in molecular biology aids in development of highly specific, sensitive, rapid and reproducible diagnostic tools for the detection of BTV. Various nucleicacid-based diagnostic techniques have been used for BT diagnosis in India.

\section{i. RNA-polyacrylamide gel electrophoresis (RNA-PAGE)} of viral nucleic acid

The RNA-PAGE has been used as a gold standard or confirmatory test for identification of segmented genome viruses such as BTV. RNA-PAGE is a very sensitive diagnostic technique, especially when associated with silver staining. It can detect up to $10^{5} \mathrm{TCID} 50 / \mathrm{ml}$ of BTV dsRNA (Prasad and Minakshi, 1999). A novel highly sensitive Eriochrome Black T (EBT)-Silver staining method for RNA-PAGE staining has been standardized, which can detect as little as 0.078ng of BTV dsRNA from various biological samples (Minakshi et al., 2013). The RNA-PAGE has been used for identification of different genotypes of the same serotype of BTV originating from different geographical regions (Prasad et al., 1998b). Multiple genetic variants within Indian isolates of BTV1 and 16 have been detected using RNA-PAGE (Minakshi et al., 2011; Ranjan et al., 2011).

\section{ii. Reverse transcription-polymerase chain reaction (RT-PCR) and PCR}

RT-PCR method can be used for direct identification of BTV in various biological samples. RT-PCR can be used for 'serogrouping' of BTV and ultimately for 'serotyping' of BTV. Primers designed from the highly conserved genes such as vp7 (Kovi et al., 2006) and ns1 (Prasad et al., 1999) are used for serogrouping of Indian isolates of BTV. The ns1-gene-based RT-PCR can detect up to 10 infectious viral particles (Prasad et al., 1999). Segment 2 is highly variable, based on which 27 serotypes of BTV have been identified. The primers specific for segment 2 of different BTV serotypes provide information on virus serotypes (Dahiya et al., 2004; Dadawala et al., 2013). The segment-6-based RT-PCR 
can also be used for further confirmation of BTV serotype (Manjunatha, et al, 2010; Ranjan et al., 2013, 2014a,b;) in addition to $\mathrm{vp} 2$ gene. To get more appropriate and accurate result, i.e. to avoid cross reactivity of BTV with other Orbiviruses, nested RT-PCR can be used. Since ns1 is a conserved gene, it was used to develop nested PCR assay, which can detect all the BTV serotypes simultaneously (Chauhan et al., 2009). The multiplex PCR can detect several different pathogens in a single PCR reaction. A sensitive multiplex reverse transcriptase polymerase chain reaction (mRT-PCR) was standardized using vp5-gene-specific primers, which can detect five different Indian BTV serotypes i.e., BTV 1, 2, 10, 16 and 23 simultaneously from various biological samples (Surendar et al., 2012).

\section{iii. Real-time reverse transcription-polymerase chain} reaction (real-time $R T$-PCR)

The Real-Time RT-PCR is based on PCR principle, which is used for amplification and simultaneous detection of desired nucleic acid molecule. The Real-time RT-PCR-based assay is now frequently used for BTV diagnosis in India because it is more specific and sensitive in comparison to conventional PCR. The primers and probe combination for each real-time RT-PCR reaction are designed to amplify and selectively detect a specific region of BTV genome such as ns1 and ns3 gene (Vishwaradhya et al., 2013; Subhadra et al., 2014).

iv. Polymerase chain reaction-restriction fragment length polymorphism (PCR-RFLP)

PCR-RFLP is a molecular biology technique that detects nucleotide variations using specific restriction enzymes in homologous DNA sequences of any species. In this technique specific region (variable region) of BTV genome is amplified by RT-PCR, which serves as template DNA for the RFLP analysis. The PCR amplicons are then digested by specific restriction enzymes and the resulting restriction fragments are detected using gel electrophoresis. The PCR-RFLP offers a much greater sensitivity and is especially useful when the pathogens occur in very small numbers. It can also be used for those microorganisms, which are difficult to culture under laboratory conditions. The PCR-RFLP-based differentiation of Indian isolates of BTV2, 10, 16 and 21 has been reported earlier (Ranjan et al., 2012; Dadawala et al., 2013; Prasad et al., 2013; Shafiq et al., 2013).

\section{v. DNA probes}

Probe-based diagnosis of BTV is based on the principle of binding (hybridization) of nucleic acid from suspected virus with highly characterized known labeled DNA called probe. The target DNA (or RNA) is extracted from clinical material or cultured cells and is either added to filters (dot or slot blot) or transferred to a filter after gel electrophoresis. A comple- mentary DNA probe amplified from BTV-serotype-specific genes can be efficiently used to characterize the viral serotype. The ns1-gene-based group-specific non-radio labeled probes has been developed for identification of Indian BTV isolates (Malik et al., 2001).

\section{vi. Nucleic acid sequencing}

The nucleic acid sequences of BTV genome are used for its genotyping or topotyping. There is a significant diversity in nucleic acid sequences that have been reported from BT viruses isolated from different geographical regions. The partial-gene-sequence-based studies of several BTV isolates in India have been done (Dahiya et al., 2004, Dadawala et al., 2013, Prasad et al., 2013; Ranjan et al., 2013, 2014a,b). In addition, the complete-genome-sequence-based studies of several Indian BTV isolates have also been performed (Maan et al., 2012a,b,c,d,e,f; Minakshi et al., 2012; Rao et al., 2012b,d; 2013a,b). The analyses of nucleic acid sequences of BTV isolates from India as well as different parts of the world provide information about its origin and geographical distribution.

\section{Prevention and control of BT}

BT causes adverse economic impact on sheep industry globally. Thus, a substantial effort is necessary to develop effective therapeutic and preventive strategies to control BT. In India it is controlled mainly by prophylactic vaccination and therapy of infected animals. However, many countries have adopted only reactive approach, which is based on outbreak crisis response, i.e. either treatment or culling of infected animals. They need to adopt a specific vaccination strategy also for BT control (Sumner et al., 2013). Other potential strategies, such as protection of livestock from Culicoides attack, may also be adopted, as observed in South Africa since the first report of BT (Verwoerd, 2012). Thus, control of BTV infection in domestic and wild ruminants can be achieved, either through protection of the animals from infection or elimination of the Culicoides vector.

\section{BT control strategy}

After the BT outbreak in Europe, strict BT control strategies have been adopted in European Union countries. According to EU Council Directive 2000/75/EC, three levels of zones have been considered for BT control (European Council, 2000). These zones are (i) $20 \mathrm{~km}$ radius zone (all animals and animal housing systems must be examined carefully by clinical and pathological laboratory tests to confirm the disease), (ii) protection zone (includes infected zone along with a radius of $100 \mathrm{~km}$ around the infected holding 
and animal movement outside from this zone is prohibited) and (iii) surveillance zone (include area of a radius of at least $50 \mathrm{~km}$ extending beyond the protection zone). The suspected clinical samples for BT diagnosis are sent to the reference laboratory of European Union (Pirbright Laboratory for Animal Health) in United Kingdom. In Australia, BT in sheep is categorized under Category 3 emergency animal disease under Australian classification of emergency animal diseases (EADs). The chief veterinary officer (CVO) along with local and national authorities will develop an Emergency Animal Disease Response Plan for the particular BT outbreak. Several measures to control BT such as treatment, quarantine and animal movement control, zoning of infected and disease-free areas, vaccination, vector control and awareness campaign to encourage cooperation from industry and community are initiated. In case of a severe outbreak, stamping out (culling of animals) policy may also be utilized (Ausvetplan, 2008). The clinical samples are sent to CSIRO - Australian Animal Health Laboratory for confirmatory diagnosis of BT. In South Africa, too, quarantine, vaccination, vector control and treatment policy is followed. The BTV serotype is confirmed at Onderstepoort Veterinary Institute.

In India, quarantine of infected/suspected animal for BT infection followed by symptomatic treatment is practiced. The nationwide BT surveillance program i.e. "All India network programme on bluetongue" (AINP-BT) have been initiated for identification of BTV serotypes and vaccine development according to local serotype prevalence. The suspected clinical samples of BT are sent to national typing center on Bluetongue, LLR University of Veterinary and Animal Sciences, Hisar, Haryana to confirm the serotype of the virus. Moreover, an Indo-UK collaborative program "India Bluetongue Vector Network" (IBVNet) has been initiated for surveillance of Culicoides vector and its role in BTV transmission in rural India.

\subsection{Control strategies based on animal involvement}

\subsubsection{Vaccination of animals}

Vaccination is used as central defense against BTV outbreak in many countries. Vaccination can reduce the economic losses by decreasing animal mortality and makes safe transfer and trading of animals and their products from one country to other. Vaccination may prevent the clinical form of BT and it may mitigate its course by interrupting the BTV cycle in the environment (Savini et al., 2008; Bhanuprakash et al., 2009). Ideally, vaccination should be against all 27 serotypes because of very low cross-protection between different serotypes. Therefore, BT vaccines should be serotype-specific. Thus, before the use of BT vaccine in an area, the serotype prevalent in that area should be taken into account (Bhanuprakash et al., 2009). Furthermore, there is a serious drawback in terms of availability of safe vaccines for BTV. In most of the countries either modified live virus (MLV) vaccines or inactivated vaccines are used. MLV vaccines have been used to control BT in several countries, such as in South Africa, USA, Israel and several parts of Europe (Dungu et al., 2004b; Shimshony, 2004; Savini et al., 2008; Wilson et al., 2009). However, MLV cannot be considered as safe for vaccination. MLV viruses may either revert back to virulent strain or reassort with other field viruses. Thus, it may be a reason for spread of vaccine-like viruses from vaccinated to unvaccinated animals, which are associated with serious BT outbreaks (Savini et al., 2008; Gollapalli et al., 2012). Moreover, MLV vaccines can also cross the placenta to infect the fetus and may lead to abortions, stillbirths and fetal abnormalities in cattle (Maclachlan and Osburn, 2008; Savini et al., 2008).

In India, sheep and goat are reared mostly by small farmer or nomadic herdsmen. Therefore, vaccination with MLV is not possible throughout the country. Moreover, it may result in spread of MLV-like virus in unvaccinated flocks or its reassortant virus with previously persisting field virus, causing serious BT outbreak in animals. Due to serious side effects of MLV, inactivated vaccines against BTV may be a choice. They neither reassort with field or MLV viruses nor cross the placenta to cause reproductive losses. It was used in Europe against BTV8 outbreak. Some of the inactivated BTV vaccine preparations were also produced in India. The binary ethylenimine (BEI)-inactivated saponified vaccines for BTV1 and BTV18 were used earlier, which elicited appreciable immune response post-vaccination in Indian sheep (Pandey et al., 2006; Ramakrishnan et al., 2006). The BEI-inactivated BTV1 vaccine induced appreciable cell-mediated immune (CMI) response against heterologous virulent strain of BTV23 in Indian native sheep (Umeshappa et al., 2010). Other viral inactivating agent - hydroxylamine - was also used for preparation of inactivated vaccine in India. An inactivated vaccine for BTV18 was prepared using hydroxylamine as inactivating agent and $\mathrm{Al}(\mathrm{OH}) 3 \mathrm{gel} /$ saponin as adjuvant for immunization of Indian sheep. The vaccine induced group-specific non-neutralizing antibodies to BTV18 as soon as seven days post-vaccination and reduced the duration of viremia during next challenge with homotypic virus dose (Ramakrishnan et al., 2005). Recently, a multivalent inactivated adjuvant vaccine (Raksha Blu) containing BTV serotypes 1, 2, 10, 16 and 23 has been developed under AINP-BT of ICAR (Reddy et al., 2010). However, inactivated vaccines have relatively slow onset of immunity and are commercially unavailable for most of the serotypes.

Now, modern molecular-technology-based new generation vaccines such as recombinant canarypox virus expressing VP2 and VP5 proteins and baculovirus-expressed viruslike particles (VLPs) have been developed. However, they are not very successful mainly due to the cost effectiveness 
(Boone et al., 2007; Noad and Roy, 2009). Other approaches, such as subunit vaccination against VP2 protein, have also been explored, but expression of immunogenic VP2 is a challenge because the specific conformation of individual epitopes (DeMaula et al., 2000).

\subsubsection{Trade restrictions, culling and housing of animals}

Trade restrictions on animals and their products are an effective measure for BTV control. However, it may cause economic losses to the farming community (Papadopoulas et al., 2009). Scientifically, BTV-immune (seropositive) animals are safe for trade purposes. The animal culling has been used to stamp out the epizootics of some of the emerging diseases such as foot and mouth disease (Papadopoulas et al., 2009). Such strategies have also been tried for BT control in Europe. However, this approach was protested by a part of society and Non-Government Organizations (NGOs). Furthermore, BT cannot be controlled by culling alone because of harboring and multiplication of BTV in vector for longer time and vector transmittance to host animal. Culicoides mostly attack animals during daytime, especially in the evening. It was also reported that more severe impact of BT on animals usually occurs during late summer and autumn. Thus, minimizing exposure of sheep to Culicoides vector by seasonal and diurnal management of animal farming can also help in control of BT. The farming management practices such as mixing of a low number of cattle to sheep herd to attract vector towards cattle and stabling of animals at night were used since some time in South Africa (Verwoerd, 2012). The same BT control managerial practices can also be applied in other countries such as India.

\subsection{Control strategies based on vector involvement}

Since BTV is transmitted by Culicoides vector, its control measure should also include vector control. An effective vector control is a challenging task due to the fact that different species of Culicoides predominate in different areas. Moreover, ecology of individual Culicoides species such as their host feeding preferences, frequency of entry in host residing area and type of their breeding sites varies significantly. Therefore, for effective vector control such parameters should be taken into consideration.

\subsubsection{Control of immature Culicoides (larvae)}

The reduction of larvae population can be used as control measure for adult midges at the farm level. Such control strategies are usually achieved by removing the Culicoides breeding sites such as wastewater lagoons, standing water body and marshlands (Carpenter et al., 2008). Several Culicoides species such as Culicoides obsoletus, Culicoides imicola, and Culicoides pulicaris breed in wet soils containing organic matter. Such grounds should be completely drained and dried off.
The larvicide Abate (5\% temephos granulated with gypsum) can be applied on such soils to prevent midge breeding. The chemical larvicidal agents such as organophosphate (OP), organochlorine or pyrethroid can also be used on Culicoides breeding sites (Holbrook, 1986). However, chemical tolerance to larvae and environmental pollution may limit such approach. Alternatively, several biological agents such as mermithids (Heleidomermis magnapapula), bacteria (e.g., Bacillus thuringiensis), fungi (Lagenidium giganteum) and iridescent viruses have been used as biorational pesticides to limit the larvae growth (Kline et al., 1985; Wright and Easton, 1996; Mullens et al., 1999). Although, these biological agents are found effective in laboratory testing conditions, their field application is unknown.

\subsubsection{Control of mature Culicoides}

The adult Culicoides population can be controlled by several means such as use of decoy animal host, trapping of insect, insecticides etc. The midges biting rate to susceptible animal can be reduced by use of decoy animal hosts and trapping of adult Culicoides (Du Toit, 1962; Nevill, 1978). Cattle usually resistant to BT can be used as decoy hosts in pastures of sheep to reduce Culicoides attack and BT outbreak in sheep. Although this approach may prevent BTV transmission in sheep by $C$. imicola at certain limit, it may increase the Culicoides population at farm level and may increase risk for entire animal population because several Culicoides species are opportunistic feeders (Santiago-Alarcon et al., 2012). Moreover, cattle serve as amplifying host for BTV, which may result to a source for BTV transmission in sheep by vector (Mayo et al., 2012).

Several artificial attractants and repellants have also been evaluated as decoys to reduce the Culicoides biting to animals. Some of the Culicoides repellents, such as p-DEET and KBR2023, have been used on animals. However, their use in animals is complicated because of daily tedious application and possible toxicity due to absorption through skin (Carpenter et al., 2005). Similarly, several insect attractants (e.g. 1-octen- 3-ol, 3-n-propyl-phenol, 4-methylphenol) may be used for insect trapping. However, their efficacy on Culicoides biting and virus transmission to animal is not confirmed by available data (Cilek et al., 2003).

A variety of compounds used against ecto- and endoparasites have been found effective against Culicoides. They are usually topically administered as impregnated ear tags, pour-on products or animals dipping in organ phosphorous or synthetic pyrethroid compounds. In organized Indian farms, insecticides are used as sprays during the vectorabundant season. Treatment of sheep using insecticide dips is also an effective method of control of several ectoparasites including Culicoides. Some of the insecticides used as dips (e.g. Ektomin and Butox) or parenterally administered (e.g. Ivermectin) during rainy season were found effective in BT 
control in organized sheep breeding farm in Haryana (Prasad et al., 2009). However, due to their expensive nature, insecticides are implemented primarily in large, well-organized farms only. They are not used by small farmers. It may be a reason of higher incidence of BT outbreak in unorganized animal rearing. Due to obvious environmental concerns the use of several synthetic insecticides has been banned. Thus, now non-polluting ecofriendly bio-insecticides such as products from the Neem tree (Azadirachta indica) are getting attention (Attri and Ravi Prasad, 1980; Blackwell et al., 2004; Narladkar et al., 2006; Raj, 2014).

\section{Lessons learnt from BT for India and other countries}

BT causes serious economic losses to small ruminant farming. The BT outbreak, control and its management in India highlighted several points, which are equally applied in India as well as other BT-infested countries.

Up to date, 27 different BTV serotypes have been reported throughout the world. However, India is endemic for BT infection and a large number of BTV serotypes (22) have been reported from this country. Many of the Indian viruses have shown maximum identity with viruses from USA and South Africa, which can be easily correlated with live animal import from these countries. Therefore, during live animal import/ trade, strict guidelines for animal health, environmental safety and quarantine measure must be taken.

Due to the lack of effective treatment, prophylactic vaccination is practiced in many parts of the world. In earlier days, multivalent live attenuated/MLV vaccines were utilized as BT control. However, live virus vaccines might be a potential source of BT spread in India and other countries. The complete genome sequencing has proved the origin of several Indian BTVs from vaccine strains used in other countries (particularly USA and South Africa). Therefore, production and marketing of MLV have now been discontinued in several countries and safer inactivated and subunit vaccines have been increasingly in use.

The possibility of incursion of newer BTV strains from other episystem is a serious threat. These new viruses may either persist as pure genome or reassort the gene segments with native viruses. Moreover, the immunity against these newer viruses is inadequate in native animal population, thus their presence usually leads to serious BT outbreak. In south India, serious BT outbreaks associated with western viruses and reassortant eastern BTV strains having western segment 5 have been seen in recent past. Therefore, preparedness for such a situation in terms of early warning system and suitable vaccine availability must be exercised. The former can be achieved by establishment of effective surveillance system including neighboring countries and also the countries from where live animals and its products are imported.
The immunity condition of susceptible population against the virus circulation should be monitored to avoid a serious epidemic outbreak.

The inadequate availability of suitable vaccine especially during the seasons, in which virus did not circulate, is a shortfall for BT control. The earlier used MLVs have several disadvantages such as abortion in pregnant animals. Furthermore, farmers who did not receive proper compensation money for such losses to their animals may generate adverse reports about the MLVs. Therefore, to avoid such situation, an inactivated pentavalent vaccine has been developed in India.

BT is primarily a disease of sheep and cattle act as inapparent multiplication host. However, virulent virus from cattle showing clinical disease condition has also been isolated in southern India. It probably reflects the change of preferred host from sheep to cattle. This might have happened due to vaccination followed by development of immunity in sheep. Thus, in coming days BT may be a threat for cattle farming as well.

There is a need for direct effective communication among different stakeholders such as farmers, policy makers, veterinarians and researchers. The inadequate communications between different stakeholders may delay the diagnosis of the disease, approval of financial grants for molecular research and vaccine and other prophylactic development. Furthermore, it is essential to adequately train the field veterinarians, because they are the people, who face the greatest difficulties in implementation of various measures such as sample collection, sending of sample to reference laboratory for diagnosis, vaccination, administrative duty, etc.

\section{BTV research and future perspective}

Due to severe economic impact, Indian Council of Agricultural Research (ICAR) has funded research on BTV in India. An integrated AINP-BT program has been initiated with eleven collaborating centers throughout the country. Under this program, molecular surveillance of different BTV serotypes prevalent in India and suitable inactivated vaccine development has been accomplished. The complete genome sequences of several Indian BTVs have already been published. Moreover, an Indo-UK collaborative project (Indian bluetongue virus network- IBVNet) jointly funded by the Biotechnology and Biological Sciences Research Council (BBSRC), UK Department for International Development (DFID) and the Scottish Government was also initiated in southern states for surveys of Culicoides populations and its vector potential for BTV transmission in India. Despite the huge research on BTV and its vector in India, complete surveillance of BTV serotypes in the entire country, Culicoides species involved in BTV transmission are yet to be explored. Moreover, suitable 
BTV vaccines for different regions of the India are required as separate preparations, because BTV serotypes are not uniformly distributed in different states. The cross-reactivity studies among different BTV serotypes need to be explored due to the fact that it is difficult to prepare vaccine for all the serotypes simultaneously in single preparation. The climatic changes and anthropogenic factor intervention have made global spread of Culicoides and BTV possible. Although they are not considered a threat for human health, their potential future consequences for human health cannot be ruled out. Thus, BTV and its Culicoides vector need to be addressed by biomedical point of view too. Moreover, it was observed by several scientists that wild type BTVs has oncolytic potentials for human cancer cells but not for normal cells (Hu et al., 2008; $\mathrm{Li}, 2011)$. Thus, their role as oncolytic agent in human cancer therapy should be explored.

\section{Conclusion}

BT is endemic in Indian subcontinent mostly due to its tropical monsoon climate, which favors its Culicoides vector. Although 22 different BTV serotypes have been reported from India, there is a lack of substantial information about temporal and spatial distribution of BTV serotypes. BTV is prevalent in the entire country, especially in South Indian states such as Andhra Pradesh, Tamil Nadu and Karnataka. Some of the BTV serotypes such as BTV4, 6, 17, 18 and 23, which were reported earlier, are absent at this time, whereas BTV1, 2,10, 12, 16 and 21, which were not isolated earlier, are now predominant serotypes. The Indian BTV isolates belong to both eastern as well as western topotypes and their reassortant strains. However, in the last decade some of the BT outbreaks appear due to the entry of newer foreign serotypes to India. Most of these serotypes are very close to South African and USA modified live vaccine viruses. These viruses entered India probably due to the import of infected animals or animals vaccinated with modified live virus vaccines. Therefore, continuous surveillance system is required for monitoring the circulation of these viruses in India. Moreover, several BTV serotypes reported during recent BT outbreak were contained a western segment 5 reassortment. Thus, question arises whether the introduction of western segment 5 can be correlated with an increase in virulence of BTV and do the more virulent strains in India contain western segment 5 ? The circulation of a large number of serotypes forced the development of sensitive diagnostic tests and vaccination. For viral pathogen identification (serotyping) many of the modern sensitive diagnostic tests such as RT-PCR, Real-Time PCR, multiplex PCR and nucleic-acid-sequencing-based assays have been developed. Recently, a pentavalent inactivated vaccine for most common serotypes circulating in India has been developed. Several herbal insecticides and synthetic pesticides have been in use for vector population control.

Supplementary information is available in the online version of the paper.

Acknowledgements. Authors are thankful to Sardar Vallabhbhai Patel University of Agriculture and Technology, Meerut, Uttar Pradesh, India for providing infrastructural facility.

\section{References}

Archana M, D'Souza PE, Prasad RC, Byregowda SM: Vet. World. 7, 517-521, 2014. http://dx.doi.org/10.14202/ vetworld.2014.517-521

Arun S, John K, Ravishankar C, Mini M, Ravindran R, Prejit N: Tropical Biomed. 31, 26-30, 2014.

Attri BS, Ravi Prasad G: Indian J. Entomol. 42, 371, 1980.

Audarya SD, Pandey AB, Nandi S, Chauhan RS: Indian J. Small Ruminants 21(1), 135-137, 2015. http://dx.doi. org/10.5958/0973-9718.2015.00030.6

Ausvetplan: http://www.animalhealthaustralia.com, 2008.

Balam D, Daggupati S, Maddireddy H: Vet. World. 4(10), 444-448, 2011. http://dx.doi.org/10.5455/vetworld.2011.444-448

Balumahendiran M, Sreenivasulu D, Kumar CA, Suryanarayana VV, Byregowda SM: Res. Vet. Sci. 86(2), 328-332, 2009. http://dx.doi.org/10.1016/j.rvsc.2008.05.017

Batten CA, Maan S, Shaw AE, Maan NS, Mertens PP: Virus Res. 137, 56-63, 2008. http://dx.doi.org/10.1016/j. virusres.2008.05.016

Belhouchet M, Mohd Jaafar F, Firth AE, Grimes JM, Mertens PP, Attoui H: PLoS One 6, e25697, 2011. http://dx.doi. org/10.1371/journal.pone.0025697

Bhanuprakash V, Indrani BK, Hosamani M, Balamurugan V, Singh RK: Expert Reviews Vaccines. 8, 191-204, 2009. http:// dx.doi.org/10.1586/14760584.8.2.191

Bhatnagar PG, Prasad, Kakkar NK, Dasgupta SK, Rajpurohit BS, Srivastava RN: Indian J. Anim. Sci. 67, 486-488, 1997.

Bisht B, Mondal B, Biswas SK, Chand K, Pandey AB: Indian J. Comp. Microbiol. Immunol. Infect. Dis. 32(1\&2), 27 29, 2011

Biswas SK, Chand K, De A, Pandey LK, Mohapatra JK, Prasad G, Monda, B: Arch. Virol. 155, 2041-2046, 2010. http:// dx.doi.org/10.1007/s00705-010-0794-X

Bitew M, Nandi S, Ravishankar C, Somvanshi R: African J. Biotech. 12(19), 2699-2705, 2013.

Blackwell A, Evans KA, Strang RH, Cole M: Med. Vet. Entomol. 18(4), 449-452, 2004. http://dx.doi.org/10.1111/j.0269283X.2004.00515.X

Bommineni YR, Reddy YN, Rao PP, Sudheer D, Susmitha B, Sarma BJ, Subba Rao MV: Vet. Record. 163, 545-546, 2008. http:// dx.doi.org/10.1136/vr.163.18.545

Boone JD, Balasuriya UB, Karaca K, Audonnet JC, Yao J, He L, Nordgren R, Monaco F, Savini G, Gardner IA, Maclachlan NJ: Vaccine, 25, 672-678, 2007. http://dx.doi.org/10.1016/j. vaccine.2006.08.025 
Carpenter S, Eyres K, McEndrick I, Smith L, Turner J, Mordue W, Mordue AJ: Parasit. Res. 95, 427-429, 2005. http://dx.doi. org/10.1007/s00436-005-1298-6

Carpenter S, Mellor PS, Torr SJ: Med. Vet. Entomol. 22, 175187, 2008. http://dx.doi.org/10.1111/j.1365-2915 $.2008 .00743 . \mathrm{x}$

Chandel BS, Chauhan HC, Kher HN: Trop. Anim. Health. Prod. 35(2), 99-104, 2003. http://dx.doi.org/10.1023/ A:1022896117122

Chander S, Prasad G, Jain NC: Vet. Microbiol. 1, 289-294, 1991. http://dx.doi.org/10.1016/0378-1135(91)90083-R

Chauhan HC, Biswas SK, Chand K, Rehman W, Das B, Dadawala AI, Chandel BS, Kher HN, Mondal B: Rev. Sci. Tech. Off. Int. Epiz., 33 (3), 1-21, 2014.

Chauhan HC, Kher HN, Chandel BS, Dadawala AI, Jain L, Agrawal SM, Bhadaniya A: Vet. World. 2(5), 179-182, 2009.

Cilek JE, Kline DL, Hallmon CF: J. Vector Ecol. 28, 23-30, 2003.

Coetzee P, Stokstad M, Venter EH, Myrmel M, Van Vuuren M: Virol J. 9, 198, 2012. http://dx.doi.org/10.1186/1743$\underline{422 X-9-198}$

Dadawala AI, Biswas SK, Rehman W, Chand K, De A, Mathapati BS, Kumar P, Chauhan HC, Chandel, BS, Mondal B: Transbound. Emerg. Dis. 59, 361-368, 2012. http://dx.doi. org/10.1111/j.1865-1682.2011.01279.x

Dadawala AI, Kher HS, Chandel BS, Bhagat AG, Chauhan HC, Ranjan K, Minakshi P: Adv. Anim. Vet. Sci. 1 (4S), 24-29, 2013.

Dahiya S, Prasad G, Minakshi, Kovi RC: DNA Seq. 15, 351-361, 2004. http://dx.doi.org/10.1080/10425170400012941

Dalal S, Prasad G, Prasad M, Maan S: Indian J. Exp. Biol. 47(4), 245-249, 2009.

Darpel KE, Batten CA, Veronesi E, Shaw AE, Anthony S, Bachanek-Bankowska K, Kgosana L, Bin-Tarif A, Carpenter S, Muueller-Doblies UU, Takamatsu HH, Mellor RS, Mertens PPC, Oura CAL: Vet. Rec. 161, 253-261, 2007. http://dx.doi.org/10.1136/vr.161.8.253

Dasgupta SK: HAU Press, pp. 115-188, 1995.

Dasgupta SK: Sci Cult. 28(11), 537-539, 1962.

De A, Batabyal S, Biswas SK, Chand K, Singh RK, Mondal B: Vet. Ital. 45(2), 339-346.

DeMaula CD, Bonneau KR, Maclachlan NJ: Virus Res. 67, 59-66, 2009. http://dx.doi.org/10.1016/S0168-1702$\underline{(00) 00130-1}$

Desai GS, Hosamane M, Kataria RS, Patil SS, Prabhudas K, Singh RK, Bhanuprakash V, Mondal B: Transbound. Emerg. Dis. 56(8), 329-336, 2009. http://dx.doi.org/10.1111/j.18651682.2009.01089.x

Du Toit RM: J. South Afr. Vet. Med. Assoc. 33, 483-490, 1962.

Dungu B, Gerdes T, Smit T: Vet. Ital. 40, 616-622, 2004a.

Dungu B, Potgieter C, Von TB, Smit T: Dev. Biol. (Basel), 119, 463-472, 2004b.

Elbers ARW, Backx A, Mintiens K, Gerbier G, Staubach C, Hendrickx G, van der Spek A: Preventive Vet. Medicine 87, 31-40, 2008. http://dx.doi.org/10.1016/j. prevetmed.2008.06.003

European Council: Off. J. L. 327, 74-83, 2000.

Fukusho A, Yu Y, Yamaguchi S, Roy P: J. Gen. Virol. 70 (Pt 7),16771689, 1989. http://dx.doi.org/10.1099/0022-1317-70-7$\underline{1677}$
Ganesh Udupa K: Ph.D. Thesis Tamil Nadu Veterinary and Animal Sciences University. Chennai, India, 2001.

Garg AK, Prasad G: Indian J. Anim. Sci. 65, 1-7, 1995.

Garg AK, Prasad G: Indian J. Virol. 10, 97-103, 1994.

Gollapalli SR, Mallavarapu S, Uma M, Rao PP, Susmitha B, Prasad PU, Chaitanya P, Prasad G, Hegde NR, Reddy YN: Transbound. Emerg. Dis. 59, 165-172, 2012. http://dx.doi. org/10.1111/j.1865-1682.2011.01266.x

Gould AR:VirusRes. 7, 169-183, 1987.http://dx.doi.org/10.1016/01681702(87)90078-5

Halder A, Joardar SN, Parui P, Banerjee D, Kumar V, Samanta I, Lodh C: Adv. Anim. Vet. Sci. 1(4S), 45-50, 2013.

Harbola PC, Chaudhary PG, Krishna L, Siriguppi BS, Kole RS: Indian. J. Comp. Microbiol. Immunol. Infec. Dis. 3, 121-127, 1982.

Hassan SH and Roy P: J. Virol. 73, 9832-9842, 1999.

Hassan SH, Wirblich C, Forzan M and Roy P: J. Virol. 75, 83568367, 2001. http://dx.doi.org/10.1128/JVI.75.18.8356$\underline{8367.2001}$

Hofmann MA, Renzullo S, Mader M, Chaignat V, Worwa G, Thuer B: Emerg. Infect. Dis. 14, 1855-1861, 2008. http://dx.doi. org/10.3201/eid1412.080818

Holbrook FR: J. Econ. Entomol. 79, 1127-1129, 1986. http://dx.doi. org/10.1093/jee/79.4.1127

Hu J, Dong CY, Li JK, Chen DE, Liang K, Liu J: Acta Oncol, 47(1), 124134, 2008. http://dx.doi.org/10.1080/02841860701403038

Hyatt AD, Zhao Y, Roy P: Virol. 193, 592-603, 1993. http://dx.doi. org/10.1006/viro.1993.1167

Ilango K: Current Sci. 90(2), 163-167, 2006.

Jain NC, Prasad G, Gupta Y, Mahajan BK: Rev. Sci. Tech. 7, 375 378,1988 .

Jain NC, Sharma R, Prasad G: Vet. Rec. 119, 17-18, 1986. http:// dx.doi.org/10.1136/vr.119.1.17

Jenckel M, Bréard E, Schulz C, Sailleau C, Viarouge C, Hoffmann B, Höper D, Beer M, Zientara S: Genome Announc. 3(2), e00016-15, 2015. http://dx.doi.org/10.1128/ genomeA.00016-15

Joardar SN, Barkataki B, Halder A, Lodh C, Sarma D: Vet. World. 6(4), 196-199, 2013. http://dx.doi.org/10.5455/ vetworld.2013.196-199

Joardar SN, Lodh C, Chakrabarti A, Baksi S, Aich R: Vet. Rec. 165, 751-752, 2009.

Kataria RS, Desai GS, Tiwari AK, Nagaleekar VK, Bandyopadhyay SK: DNA Seq. 17(1), 65-73, 2006. http://dx.doi. org/10.1080/10425170500511198

Kline DL, Kelly JF, Ellis EA: J. Invertebr. Pathol. 45, 60-65, 1985. http://dx.doi.org/10.1016/0022-2011(85)90050-3

Kovi RC, Dahiya S, Minakshi, Prasad G: DNA Seq. 17, 187-198, 2006. http://dx.doi.org/10.1080/10425170600807264

Kulkarni DD, Bannalikar AS, Karpe AG, Gujar MB, Kulkarni MN: In Bluetongue, African horse sickness and related orbiviruses (T.E. Walton \& B.I. Osburn, Eds). Proc. Second International Symposium, Paris, 17-21 June 1991. CRC Press, Boca Raton, 85, 1992.

Kulkarni DD, Kulkarni MN: Indian J. Comp. Microbiol. Imunol. Infect. Dis. 5, 125, 1984.

Kumar P, Minakshi P, Ranjan K, Dalal R, Prasad G: Adv. Anim. Vet. Sci. 1 (4S), 14-19, 2013. 
Li JK: Front Microbiol. 2, 46, 2011.

Loudon PT, Roy P: Virol. 191, 231-236, 1992. http://dx.doi. org/10.1016/0042-6822(92)90184-Q

Luedke AJ, Jones RH: Bovine Practice 15, 70-86, 1984.

Maan NS, Maan S, Guimera M, Nomikou K, Morecraft E, Pullinger G, Belaganahalli MN, Mertens PPC: J. Virol. 86, 63756376, 2012e. http://dx.doi.org/10.1128/JVI.00671-12

Maan NS, Maan S, Guimera M, Pullinger G, Singh KP, Nomikou K, Belaganahalli MN, Mertens PPC: J. Virol. 86, 5404-5405, 2012b. http://dx.doi.org/10.1128/JVI.00420-12

Maan NS, Maan S, Nomikou K, Guimera M, Pullinger G, Singh KP, Belaganahalli MN, Mertens PPC: J. Virol. 86, 5967-5968, 2012d. http://dx.doi.org/10.1128/JVI.00536-12

Maan NS, Maan S, Nomikou K, Prasad G, Singh KP, Belaganahalli MN, Mertens PP: J. Virol. 86, 4717-4718, 2012a. http:// dx.doi.org/10.1128/JVI.00188-12

Maan S, Maan NS, Belaganahalli MN, Rao PP, Singh KP, Hemadri D, Putty K, Kumar A, Batra K, Krishnajyothi Y, Chandel BS, Reddy GH, Nomikou K, Reddy YN, Attoui H, Hegde NR, Mertens PP: PLoS One. 10(6), e0131257, 2015. http:// dx.doi.org/10.1371/journal.pone.0131257

Maan S, Maan NS, Guimera M, Nomikou K, Singh KP, Pullinger G, Belaganahalli MN, Mertens PPC: J. Virol. 86, 7011-7012, 2012f. http://dx.doi.org/10.1128/JVI.00731-12

Maan S, Maan NS, Nomikou K. Batten C, Antony F, Belaganahalli MN, Attia MS, Reda AA, Al-Rashid SA, El Batel M, Oura CAL, Mertens PPC: Emerg. Infect. Dis. 17, 886-889, 2011. http://dx.doi.org/10.3201/eid1705.101742

Maan S, Maan NS, Pullinger G, Nomikou K, Morecroft E, Guimera M, Belaganahalli MN, Mertens PPC : J. Virol. 86, 59715972, 2012c. http://dx.doi.org/10.1128/JVI.00596-12

Maan S, Maan NS, Ross-smith N, Batten CA, Shaw AE, Anthony SJ, Samuel AR, Darpel KE, Veronesi E, Oura CA, Singh KP, Nomikou K, Potgieter AC, Attoui H, van Rooij E, van Rijn P, De Clercq K, Vandenbussche F, Zientara S, Bréard E, Sailleau C, Beer M, Hoffman B, Mellor PS, Mertens PP: Virol. 377, 308-318, 2008. http://dx.doi.org/10.1016/j. virol.2008.04.028

Maan S, Maan NS, van Rijn PA, van Gennip RGP, Sanders A, Wright IM, Batten C, Hoffmann B, Eschbaumer M, Oura CAL, Potgieter AC, Nomikou K, Mertens PPC: PLoS ONE, 5(4), e10323, 2010. http://dx.doi.org/10.1371/journal. pone. 0010323

Maclachlan NJ, Guthrie AJ: Vet. Res. 41, 35, 2010. http://dx.doi. org/10.1051/vetres/2010007

Maclachlan NJ, Osburn BI: Vet. Rec. 162, 490-491, 2008. http:// dx.doi.org/10.1136/vr.162.15.490-b

Mahajan NK, Prasad G, Jain NC, Dhanoea JS, Gupta Y: Ind. J. Anim. Sci. 61, 1-5, 1991.

Malik Y, Minakshi, Dahiya S, Ramesh K, Pawan K, Prasad G: Indian. J. Anim. Sci. 72, 551-552, 2002.

Malik Y, Prasad G, Minakshi, Maan S: Indian J. Anim. Sci. 71, 501-503, 2001.

Manjunatha BN, Prasad M, Maan S, Prasad G: Indian J. Biotech. 9, 117-125, 2010.

Mayo CE, Mullens BA, Gerry AC, Barker CM, Mertens PP, Maan S, Maan N, Gardner IA, Guthrie AJ, Maclachlan NJ: Vet.
Parasitol. 187, 295-301, 2012. http://dx.doi.org/10.1016/j. vetpar.2012.01.004

Mehlhorn H, Walldorf V, Klimpel S, Schmahl G: Parasitology Res. 103, 79-86, 2008. http://dx.doi.org/10.1007/s00436-008 $\underline{-1100-7}$

Mehrotra ML, Shukla DC, Khanna PN: Indian J. Comp. Microbiol. Immunol. Infect. Dis. 17, 8-13, 1996.

Mehrotra ML, Shukla DC, Singh KP, Khanna PN, Saikumar G: Indian J. Comp. Microbiol. Imunol. Infect. Dis. 16, 135-136, 1995.

Mehrotra ML, Sukla DC: Indian. J. Anim. Sci. 54, 718, 1984.

Mertens PPC, Brown F, Sanger DV: Virol. 135, 207-217, 1984. http:// dx.doi.org/10.1016/0042-6822(84)90131-4

Minakshi P, Ranjan K, Bhateja A, Shafiq M, Kumar A, Prasad G: Indian J. Field Vet. 7(2), 63-68, 2011.

Minakshi P, Ranjan K, Kumar P, Prasad G: Adv. Anim. Vet. Sci. 1 (4S), 20-23, 2013.

Minakshi P, Singh R, Ranjan K, Kumar P, Joshi CG, Reddy YKM, Prasad G: J. Virol. 86(15), 8337, 2012. http://dx.doi. org/10.1128/JVI.01128-12

Mondal B, Bisht B, Biswas SK, Chand K: Vet. Ital. 49(4), 375-380, 2013.

Mondal B, Sen A, Chand K, Biswas SK, De A, Rajak KK, Chakravarti S: Trop. Anim. Health. Prod. 41(8), 1661-1667, 2009. http://dx.doi.org/10.1007/s11250-009-9362-3

Mullens BA, Velten RK, Federici BA: J. Invert. Path. 73, 231-233, 1999. http://dx.doi.org/10.1006/jipa.1998.4838

Narayana and Manicham R: National symposium on Advances in diagnosis and therapeutic measures of diseases of ruminants, companion and other animals. Abstr. p. 55, 1997.

Naresh A, Prasad G: Indian J. Exp. Biol. 33, 880-882, 1995.

Naresh A, Roy P, Prasad G: Am. J. Vet. Res. 57, 1556-1558, 1996.

Narladakar BW, Shastri UV, Shivpuje PR: Indian Vet. J. 70, 116-118, 1993.

Narladkar BW, Deshpande, Vaniprasad V, Vadlamudi, Shivpuje PR, AR Deshpande: J. Vet. Parasitol. 20(2), 125-128, 2006.

Nason EL, Rothagel R, Mukherjee SK, Kar AK, Forzan M, Prasad BVV and Roy P: J. Virol. 78, 8059-8067, 2004. http:// dx.doi.org/10.1128/JVI.78.15.8059-8067.2004

Nevill EM: J. South Afr. Vet. Assoc. 49, 129-130, 1978.

Noad R, Roy P: Vaccine 27 (suppl.4), D86-D89, 2009. http://dx.doi. org/10.1016/j.vaccine.2009.08.037

OIE: http://www.oie.int/animal-health-in-the-world/oie-listeddiseases-2013/, 2013.

Osburn BI, McGowan B, Heron B, Loomis E, Bushnell R, Stott JL: Am. J. Vet. Res. 42, 884-887, 1981.

Owens RJ, Limn C and Roy P: J. Virol. 78, 6649-6656, 2004. http:// dx.doi.org/10.1128/JVI.78.12.6649-6656.2004

Pandey AB, Nandi S, Dubey SC, Sonawane GG, Mondal B, Bhanuprakash V, Audarya SD, Suresh I, Sharma K, Prasad G, Singh RK, Singh N, Chauhan RS: J. Immuno. Immunopathol. 8(2), 146-154, 2006.

Papadopoulas O, Mellor PS, Mertens PP: Elsevier, Amsterdam, 429-452, 2009.

Patel AR, Chandel BS, Chauhan HC, Pawar DW, Bulbule NR, Bhalodia SD, Kher HN: Ind. Vet. J. 3, 33-36, 2007.

Prasad G, Garg AK, Minakshi, Kakker NK, Srivastava RN: Rev. Sci. Tech. 13, 935-938, 1994 
Prasad G, Jain NC, Mahajan NK, Vasudevan B: Ind. J. Anim. Sci. 57, 522-524, 1987.

Prasad G, Malik P, Malik PK and Minakshi: Indian J. Virol. 14, 51-53, 1998a.

Prasad G, Minakshi, Maan S, Malik Y: Indian J. Microbiol. 38, 161-163, 1998b.

Prasad G, Minakshi, Malik Y, Maan S: Indian J. Exp. Biol. 70, 103-109, 1999.

Prasad G, Minakshi: Indian J. Exp. Biol. 37, 157-160, 1999.

Prasad G, Sreenivasulu D, Singh KP, Mertens PPC, Maan S: Elsevier Ltd., London. 167-195, 2009.

Prasad G: Indian J. Microbiol. 40, 163-175, 2000.

Prasad M, Ranjan K, Kumar P, Prasad G: Vet. World. 6(5), 244-248, 2013. http://dx.doi.org/10.5455/vetworld.2013.244-248

Prasad M, Ranjan K, Pawan, Rupinder, Prasad G: Haryana Vet. 50, 68-71, 2011.

Pritchard LI, Gould AR, Wilson WC, Thompson L, Mertens PPC, Wade-Evans AM: Virus Res. 35, 247-261 1995. http:// dx.doi.org/10.1016/0168-1702(94)00072-K

Rahman AH, Manickam R: Onderstepoort J. Vet. Res. 64, 301307, 1997.

Raj A: Asian J. Multidisciplinary Studies. 2(9), 29-33, 2014.

Rajkhowa S, Rajkhowa C, Dutta PR, Michui P, Das R: Rev. Sci. Tech. 27(3), 907-914, 2008.

Ramakrishnan MA, Pandey AB, Singh KP, Singh R, Mehrotra ML: Vet. Italiana 41 (3), 149-155, 2005.

Ramakrishnan MA, Pandey AB, Singh KP, Singh R, Nandi S, Mehrotra ML: Vet. Res. Commun. 30, 873-880, 2006. http:// dx.doi.org/10.1007/s11259-006-3313-5

Ranjan K, Minakshi P, Kumar P, Prasad G: Adv. Anim. Vet. Sci. 2 (2), 91-97, 2014a. http://dx.doi.org/10.14737/journal. aavs/2014/2.2.91.97

Ranjan K, Minakshi P, Shafiq S, Pawan K, Prasad G: Intr. J. Appl. Eng. Res. 6(5), 884-887, 2011.

Ranjan K, Prasad G, Kumar P, Minakshi P: Adv. Anim. Vet. Sci. 1 (4S), 30 - 36, 2013.

Ranjan K, Prasad G, Kumar P, Minakshi P: Adv. Anim. Vet. Sci. 2(2), 98-103, 2014b. http://dx.doi.org/10.14737/journal. aavs/2014/2.2.98.103

Ranjan K, Prasad M, Harimohan, Rupinder, Vishwaaradhya TM, Prasad G: Haryana Vet. 51, 29-33, 2012.

Rao PP, Hegde N R, Reddy YN, Krishnajyothi Y, Reddy YV, Susmitha B, Gollapalli SR, Putty K, Reddy GH: Transbond. Emerg. Dis., 2014. http://dx.doi.org/10.1111/ tbed. 12258

Rao PP, Hegde NR, Reddy YN: J. Virol. 86, 8341, 2012a. http:// dx.doi.org/10.1128/JVI.00968-12

Rao PP, Reddy YN, Ganesh K, Nair SG, Niranjan V, Hegde NR: J. Virol. Methods 193, 314-319, 2013a. http://dx.doi. org/10.1016/j.jviromet.2013.06.033

Rao PP, Reddy YN, Hegde NR: J. Virol. 86, 8333, 2012c. http:// dx.doi.org/10.1128/JVI.01101-12

Rao PP, Reddy YV, Hegde NR: Transbound. Emerg. Dis. 2013b. http://dx.doi.org/10.1111/tbed.12199

Rao PP, Reddy YV, Meena K, Karunasree N, Susmitha B, Uma M, Prasad PUVS, Chaitanya P, Reddy YN, Hegde NR: Virus Genes 44, 1-9, 2012d. http://dx.doi.org/10.1007/ s11262-011-0707-4
Rao PP, Reddy YV, Meena K, Karunasree N, Susmitha, B, Uma M, Prasad PUVS, Chaitanya P, Reddy YN, Hegde NR: 44, 286-294, 2012b.

Ravishankar C, Krishnan Nair G, Mini M, Jayaprakasan V: Indian Rev. Sci. Tech. 24(3), 953-958, 2005.

Reddy CVS, Hafeez M: Indian J. Anim. Sci.78 (2), 138-142, 2008.

Reddy CVS: M.V.Sc Thesis Acharya, N.G. Ranga Agricultural University, Tirupati. India, 2004.

Reddy YKM, Manohar BM, Pandey AB, Reddy YN, Prasad G, Chauhan RS: Indian Vet. J. 87, 434-436, 2010.

Reddy YV, Krishnajyothi Y, Susmitha B, Devi BV, Brundavanam Y, Gollapalli SR, Karunasri N, Sonali B, Kavitha K, Patil SR, Sunitha G, Putty K, Reddy GH, Reddy YN, Hegde NR, Rao PP: Transbound Emerg. Dis. http://dx.doi. org/10.1111/tbed.12320

Roy P, Adachi A, Urakawa T, Booth TF, Thomas CP: J. Virol. 64, $1-8,1990$.

Roy P, Fukusho A, Ritter DG, Lyons D: Nucleic Acids Res. 16, 11759 11767, 1988. http://dx.doi.org/10.1093/nar/16.24.11759

Roy P, Boyce M, Noad R: Nat. Rev. Microbiol. 7(2), 120-128, 2009. http://dx.doi.org/10.1038/nrmicro2052

Sairaju V, Susmith B, Rao PP, Hegde NR, Meena K, Reddy YN: Indian J. Virol. 24(3), 394-397, 2013. http://dx.doi. org/10.1007/s13337-013-0156-X

Santiago-Alarcon D, Havelka P, Schaefer HM, Segelbacher G: PLoS ONE 7, e31098, 2012. http://dx.doi.org/10.1371/journal. pone. 0031098

Sapre SN: Indian Vet. Rev. 15, 78-80, 1964.

Satheesha SP, Udupa KG, Appannavar MM, Labuschagne K: Buffalo Bulletin 33 (4), 300-306, 2014.

Savini G, Afonso A, Mellor P, Aradaib I, Yadin H, Sanaa M, Wilson W, Monaco F, Domingo M: Res. Vet. Sci. 91, 1-17, 2011. http://dx.doi.org/10.1016/j.rvsc.2011.05.004

Savini G, MacLachlan NJ, Sanchez-Vizcaino JM, Zientara S: Comp. Immuno. Microbiol. Infect. Dis. 31, 101-120, 2008. http:// dx.doi.org/10.1016/j.cimid.2007.07.006

Selvaraju G: Int. J. Sci. Res. 3(7), 74-76, 2014.

Shafiq M, Minakshi P, Bhateja A, Ranjan K, Prasad G: Virus Res. 173, 336-343, 2013. http://dx.doi.org/10.1016/j. virusres.2013.01.009

Shimshony A: Vet. Ital. 40, 116-118, 2004.

Singh KP, Maan S, Samuel AR, Rao S, Meyer AJ and Mertens PPC: Vet. Ital. 40, 479-483, 2005.

Sreenivasulu D, Subba Rao MV, Gard GP: Vet. Rec. 144, 452-453, 1999. http://dx.doi.org/10.1136/vr.144.16.452

Sreenivasulu D, Subba Rao MV, Reddy YN, Gard GP: Vet. Ital. 40, 73-77, 2004.

Subhadra S, Kumar S, Suryanarayana VVS, Sreenivasulu D: J. Infect. Dev. Ctries. 8(10), 1307-1312, 2014. http://dx.doi. org/10.3855/jidc.4681

Sumner T, Burgin L, Gloster J, Gubbins S: Epidemiol. Infect. 141, 102-114, 2013. http://dx.doi.org/10.1017/ $\underline{\text { S0950268812000532 }}$

Surendar S, Reddy YKM: Tamilnadu J. Vet. Anim. Sci. 8 (2), 101103,2012

Susmitha B, Sudheer D, Rao PP, Uma M, Prasad G, Minakshi P, Hegde NR, Reddy YN: Virus Genes 44, 466-469, 2012. http://dx.doi.org/10.1007/s11262-012-0724-y 
Tabachnick WJ, Robertson MA, Murphy KE: Ann. NY Acad. Sci. 791, 219-226, 1996. http://dx.doi.org/10.1111/j.17496632.1996.tb53528.x

Tamura K, Peterson D, Peterson N, Stecher G, Nei M, Kumar S: Mol. Biol. Evol. 28, 2731-2739, 2011. http://dx.doi.org/10.1093/ molbev/msr121

Tembhurne PA, Mondal B, Pathak KB, Biswas SK, Sanyal A, Yadav MP, Bandyopadhyay SK, Singh RK: Arch. Virol. 155, 8995, 2010. http://dx.doi.org/10.1007/s00705-009-0553-z

Umeshappa CS, Singh KP, Pandey AB, Singh RP, Nanjundappa RH: Vaccine 28(13), 2522-2531, 2010. http://dx.doi. org/10.1016/j.vaccine.2010.01.039

Uppal PK, Vasudevan B: Ind. J. Comp. Microbiol. Immunol. Infect. Dis. 1, 18-20, 1980.

Velthuis AG, Saatkamp HW, Mourits MC, de Koeijer AA, and Elbers AR: Prev. Vet. Med. 93, 294-304, 2009. http://dx.doi. org/10.1016/j.prevetmed.2009.11.007

Veronesi E, Darpel KE, Hamblin C, Carpenter S, Takamatsu HH, Anthony SJ, Elliott H, Mertens PP, Mellor PS: Vaccine 28(5), 1397-1403, 2010. http://dx.doi.org/10.1016/j. vaccine.2009.10.107
Verwoerd DW: J. South Afr. Vet. Assoc. 83, e1-e6, 2012. http:// dx.doi.org/10.4102/jsava.v83i1.532

Vishwaradhya TM, Minakshi P, Ranjan K, Supriya, Kumar P, Prasad G: Vet. World. 6(8), 554-557, 2013.

Williamson S, Woodger N, Darpel K: In Practice. 30, 242-251, 2008. http://dx.doi.org/10.1136/inpract.30.5.242

Wilson WC, Mecham JO, Schmidtmann E, Sanchez CJ, Herrero M, Lager I: Elsevier Academic Press, London, UK, 197-221, 2009.

Wright PJ, Easton CS: Aust. J. Entomol. 35, 131-134, 1996. http:// dx.doi.org/10.1111/j.1440-6055.1996.tb01376.x

Yasothai R: Int. J. Sci. Env. Technol. 2(4), 646-648, 2013.

Yousuf RW, Sen A, Mondal B, Biswas SK, Chand K, Rajak KK, Gowane GR, Sudhakar SB, Pandey AB, Ramakrishnan MA, Muthuchelvan D: Small Ruminant Res. http://dx.doi. org/10.1016/j.smallrumres.2015.01.007

Zientara S, Maclachlan NJ, Calistri P, Sanchez-Vizcaino JM, Savini G: Expert Rev. Vaccines 9, 989-991, 2010. http://dx.doi. org/10.1586/erv.10.97 